\title{
معجزة القرآن الكريم خصائصها وأثرها على ثقافة الشعوب
}

\author{
بكري محمد بخيت أحمد \\ كلية القرآن الكريم - جامعة القرآن الكريم والعلوم الإسلامية

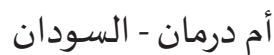 \\ Email: bakriahmad893@gmail.com
}

الملخخص

يتحدث هذا البحث عن معجزة القرآن الكريم وما حباها الله تعالى به من خصائص

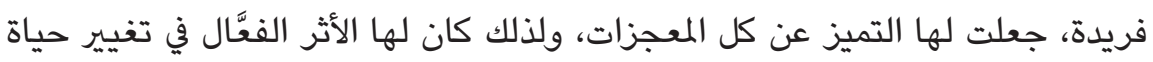

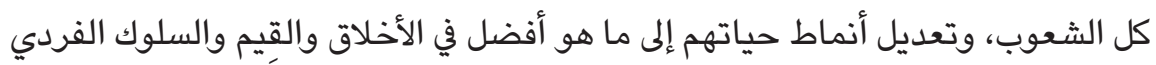

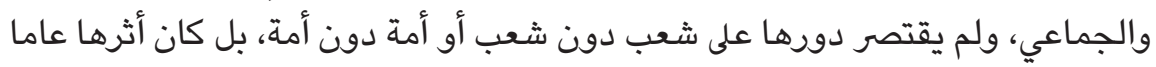
كما هي معجزة لكل العالمِين.

This study explores the miracles of the Qur'an as well as its superiorities given by Allah that distinguish it from the other miracles. One of the miracles is its power to influence and change the life of a nation into a better living, both individually and socially. The notable miracle of the Qur'an is not limited to a particular nation or community, but its effect is general as the miracle for the whole universe

الكلمات المفتاحية: معجزة القرآن؛ خصائصها؛ أثرها الثقافي

مقدمت

الحمد لله الذي أحيا الأرض بالنبات، وخلق الإنسان وعلمه بالدين والرسالات وأرسل

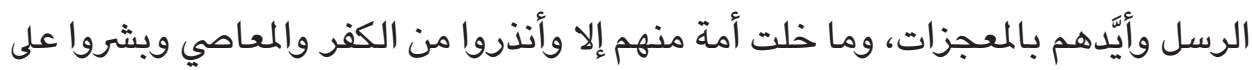




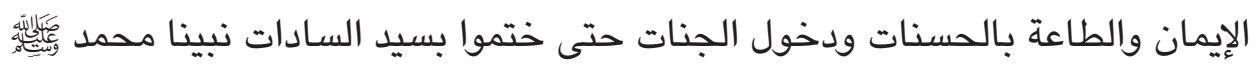
الخاتم العاقب الذي تمت به النعمة من رب السموات، فصلوات الله وسلامه عليه وعلى الفي

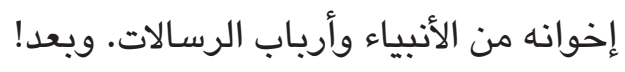

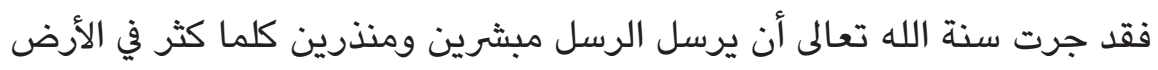

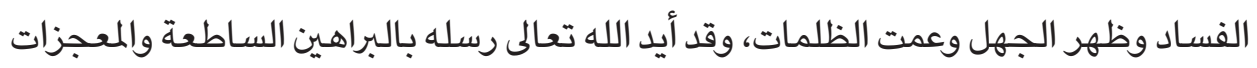

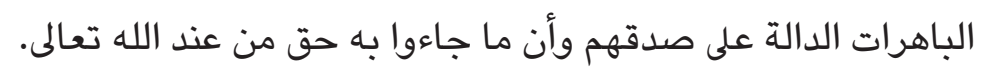

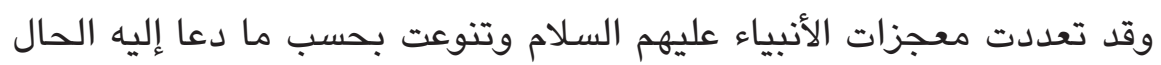

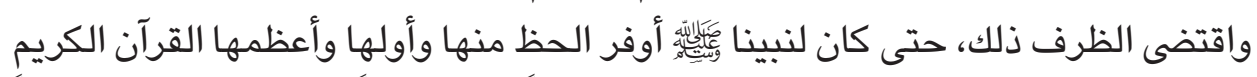

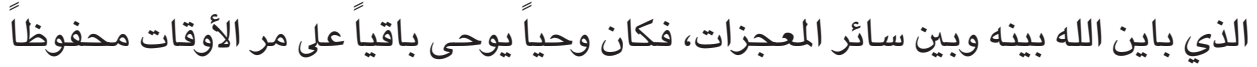

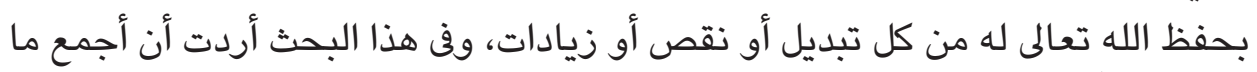

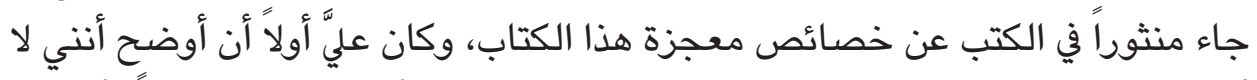

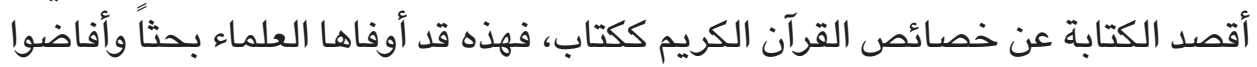

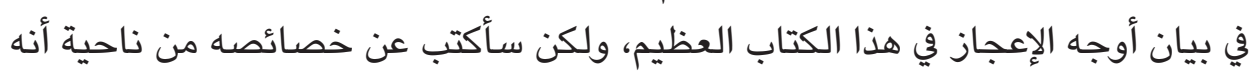

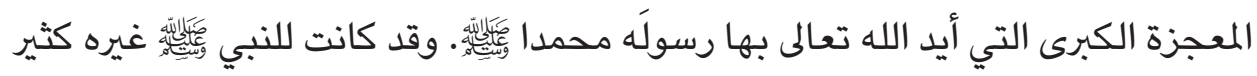

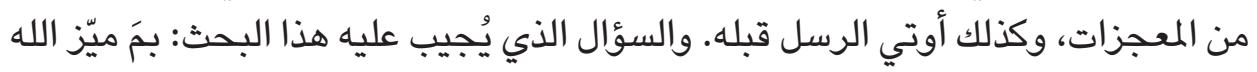

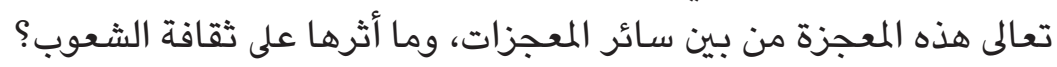
فهذا هو مقصدي وموضوع بحثي ولذا سميته (معجزة القرآن الكريم خصائصها

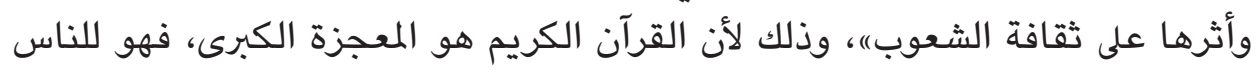

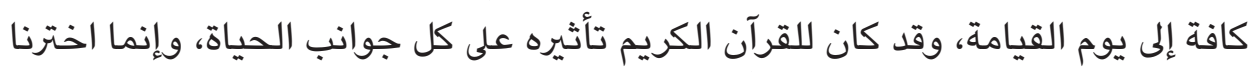

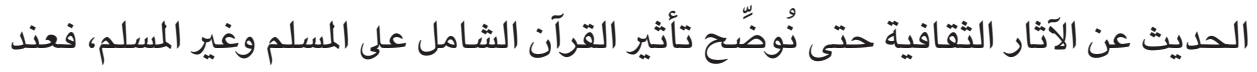

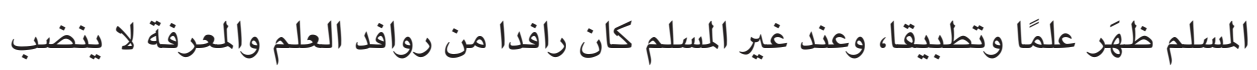
على مرّ الزمان.

وسبب اختياري لهذا الموضوع بحسب اطلاعي المتواضع أن هذا الجانب الذي تناوله

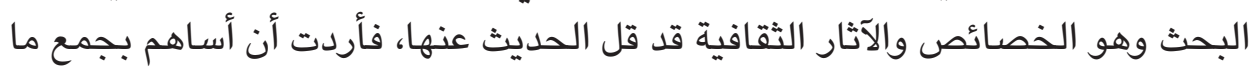
تناثر عن هذا الموضوع حتى يكون في مكان واحد. فجهدي إذن في هذا البحث هو جمع للمتفرق والمتناثر من أقوال سلفنا الصالح واحلح وعلماءنا الأجلاء وترتيبها في مباحث حتى يسهل الاطلاع عليها والاستفادة منها بإذن الله. 
واتبعت في ذلك المنهج الاستقرائي الاستنباطي في رسم وتحديد معالم هذا البحث

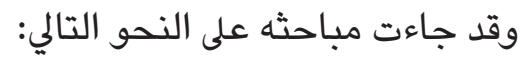
المبحث الأول: معنى المعجزة وشروطها

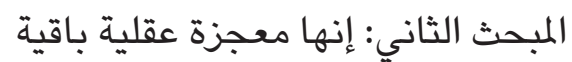
المبحث الثالث: تعدد وتجدد وجوه الإعجاز فيها المبحث الرابع: كونها حافظة وشاهدة لمعجزات المجات الأنبياء المبحث الخامس: إنها معجزة للثقلين المانئ المبحث السادس: آثارها على ثقافة الشعوب الثالين

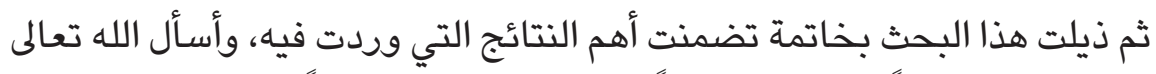
أن يكون عملي هذا صالحاً، ولوجهه خالصاً، ولا يجعل لأحد فيه شيئاً، وأن ينفع به - آمين.

\section{المبحث الأول: معنى المعجزة وشروطها

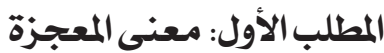

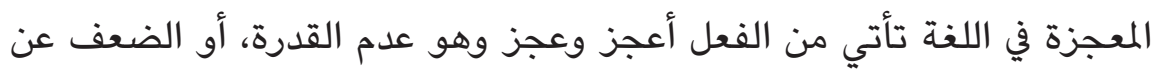

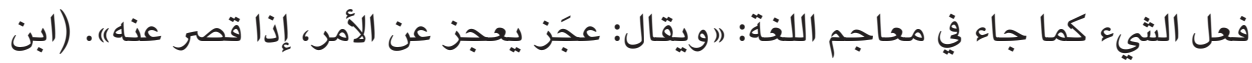

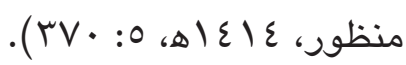

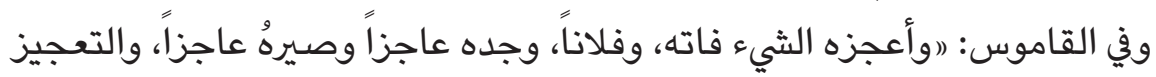

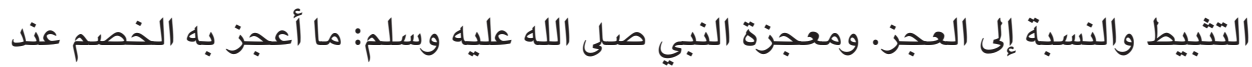

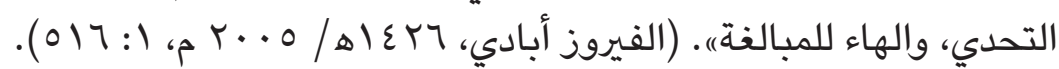

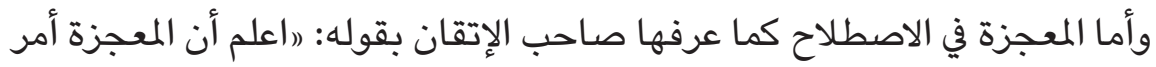

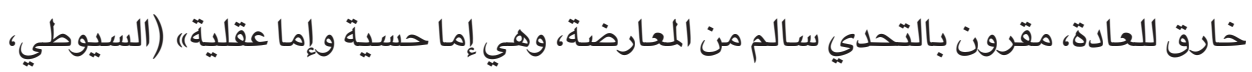

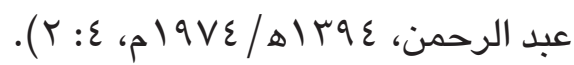

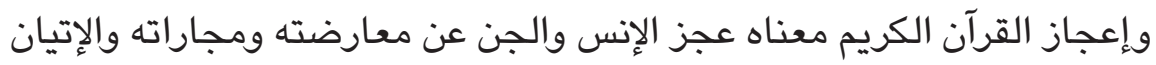

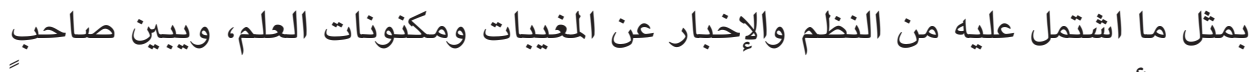

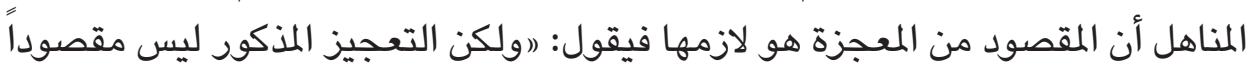

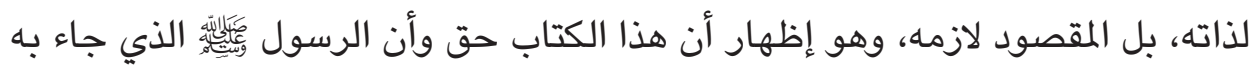

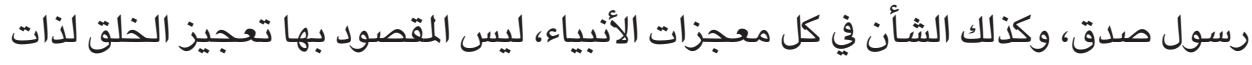

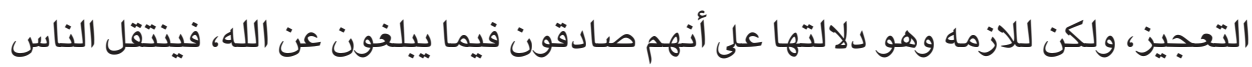
من الشعور بعجزهم إزاء المعجزات إلى شعورهم وإيمانهم بأنها صادرة عن النها الإله القادر فينتل 
لحكمة عالية وهي إرشادهم إلى تصديق من جاء بها ليسعدوا باتباعه في الدنيا والآخرةه،

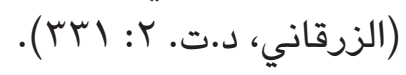

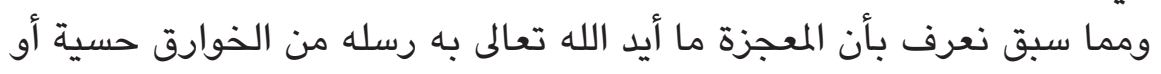

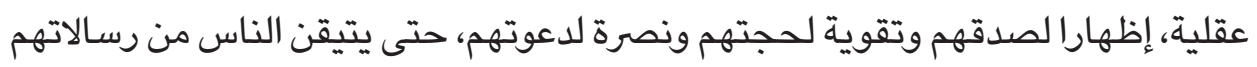
ويتبعونهم على الصراط المستقيم. ولما كانت أحوال الناس مختلفة من حيث الإيمان والتصديق، ومن حيث إنشراق قلويهم

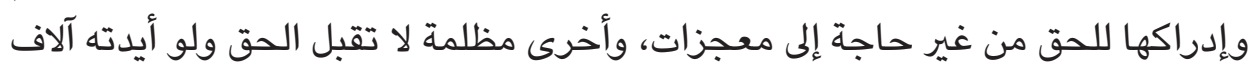

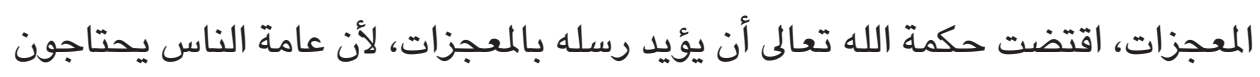

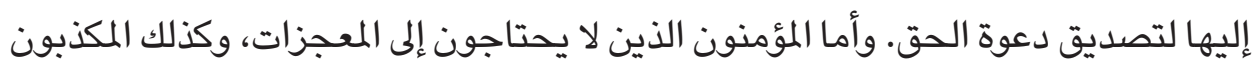

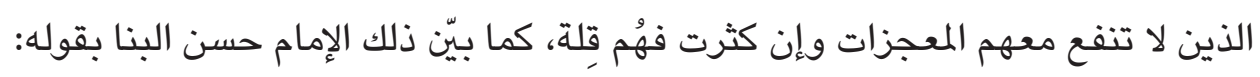

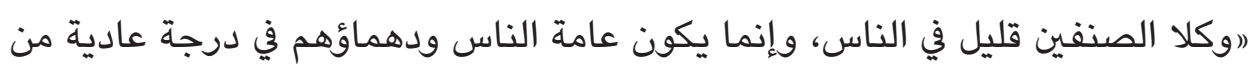

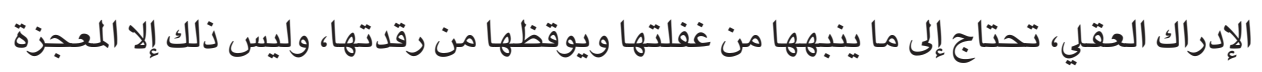

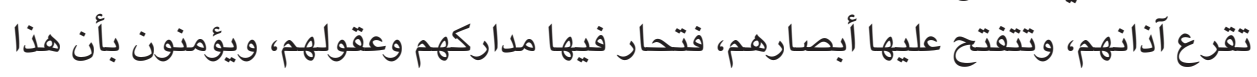

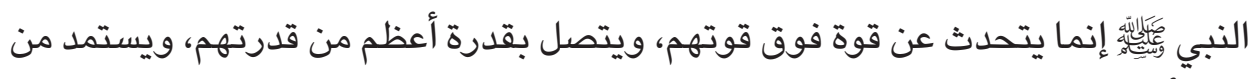

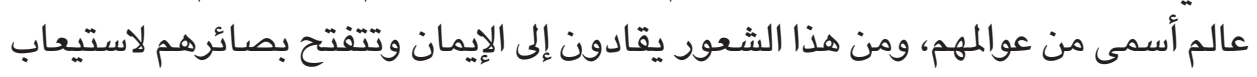

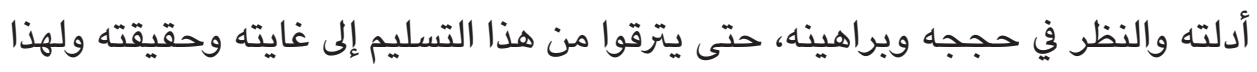

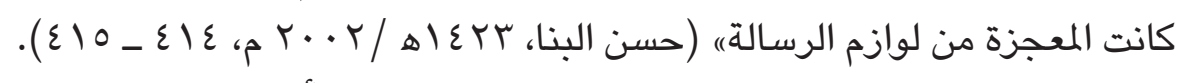

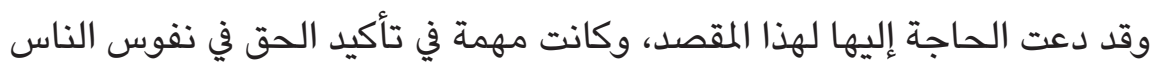
حتى يذعنوا إليه طائعين.

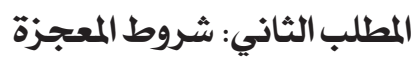

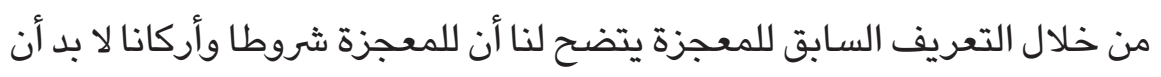

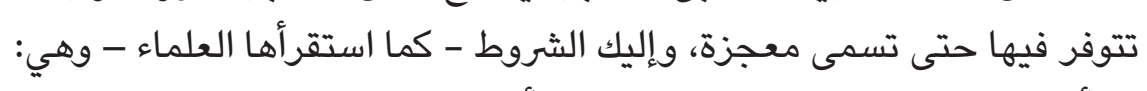

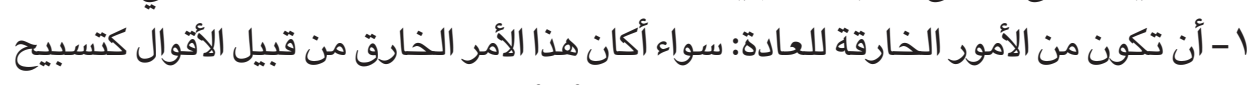

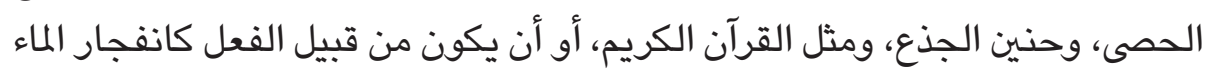

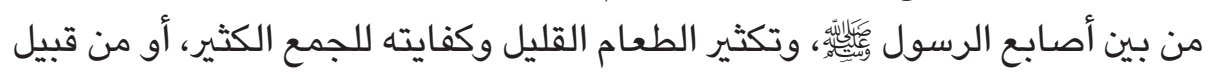

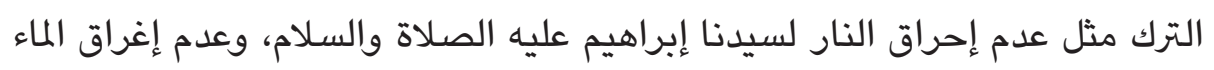
لسيدنا موسى عليه الصلاة والسلام وقومه، وعدم سيلانه عليهم.

el Harakah Jurnal Budaya Islam Vol. 19 No.1 Tahun 2017 
وأما إذا كان الأمر من الأمور الاعتيادية للناس ومع ذلك لم يستطع الناس الإتيان

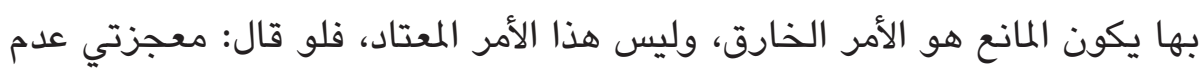

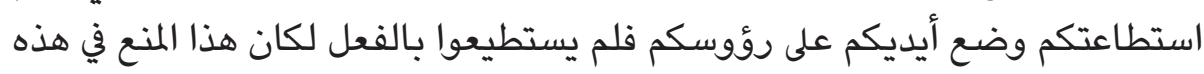
اللحظة هو المعجزة، وليس عملية وضع الأيدي.

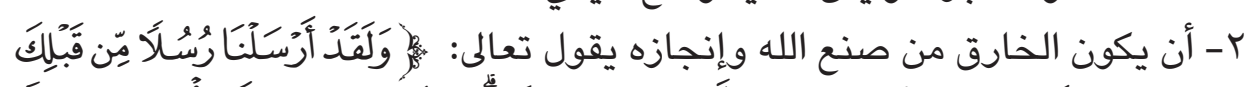

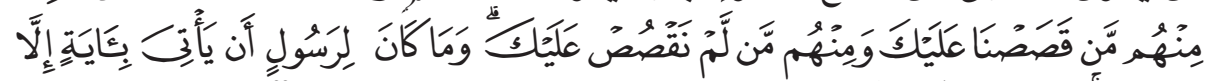

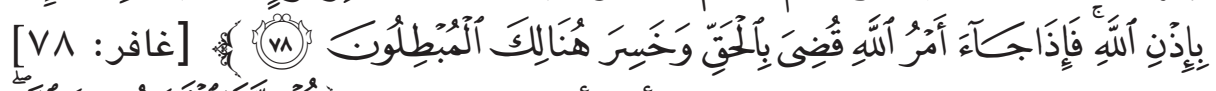

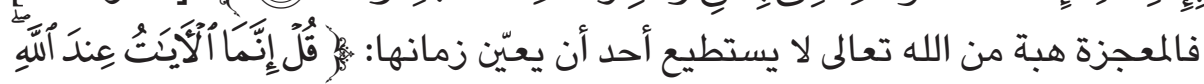

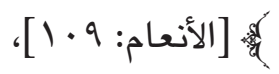

r- سلامتها من المعارضة: فلو استطاع الخصم أن يأتي بمثل ما جاء النبي بطلت حجته أنهاء

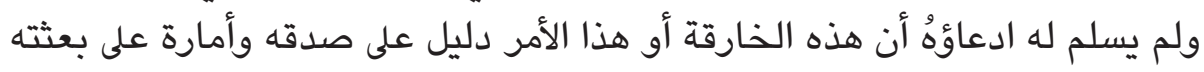

$$
\text { من قِبِل الله سبحانه وتعالى. }
$$

ع- أن تقع على مقتضى قول من يدعيها (وقوعها على مقتضى الدعوى) . يشترط في المعجزة

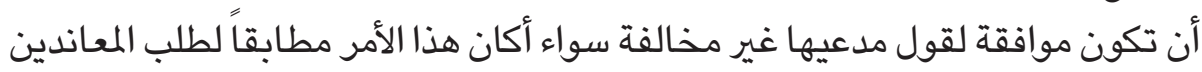

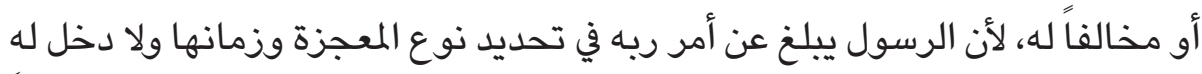

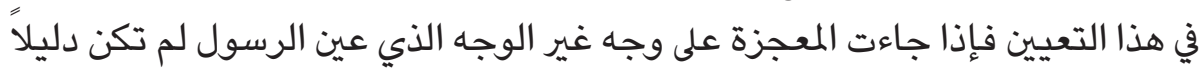

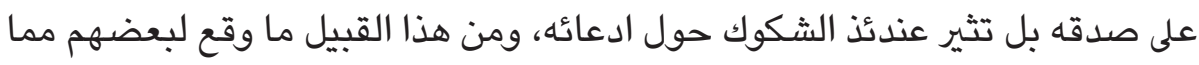

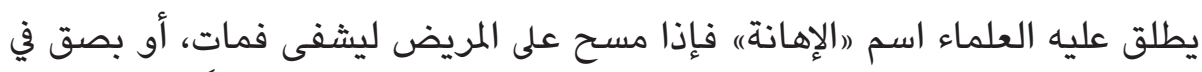

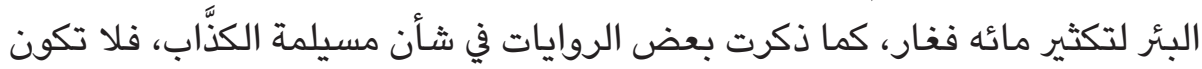

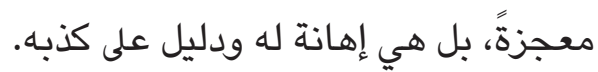

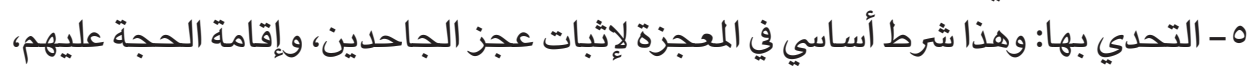

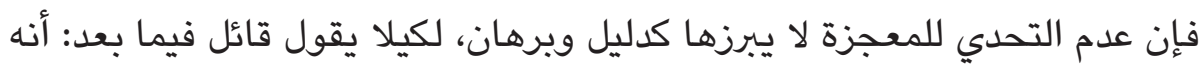

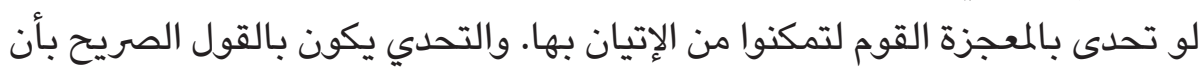

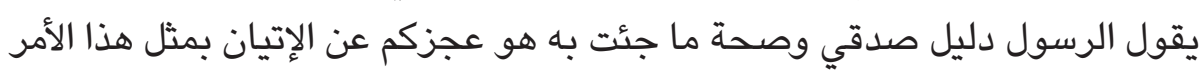

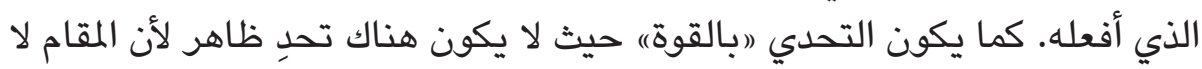

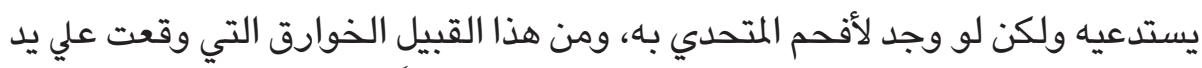

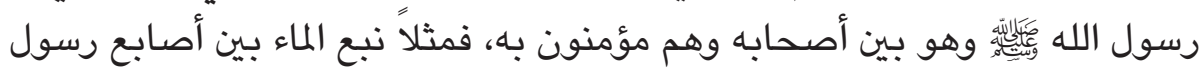

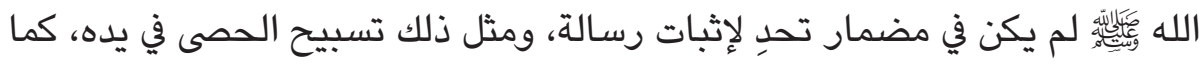




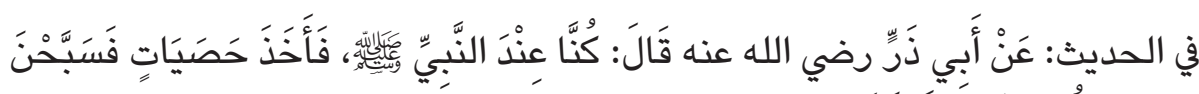

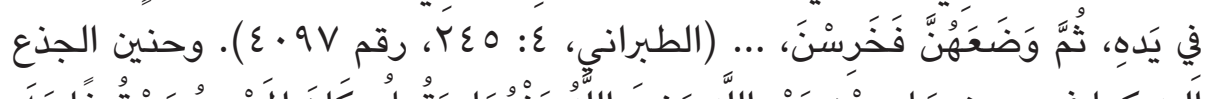

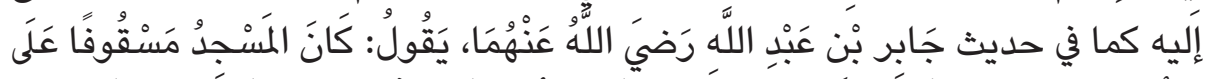

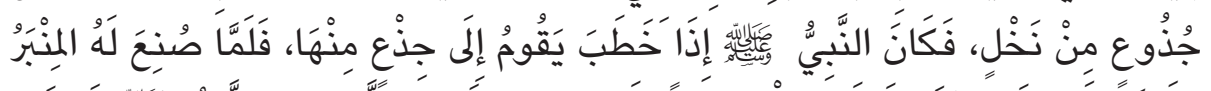

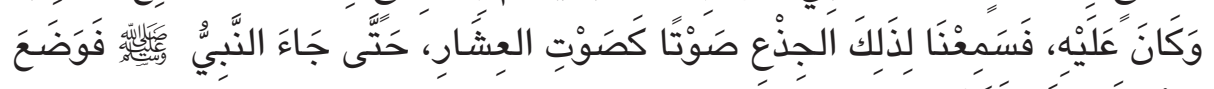

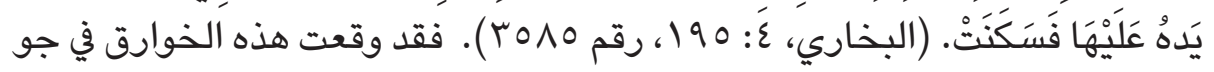
إيماني وفي مجتمع إسلامي.

وقد فرق بعض العلماء بين الخارقة التي يتحدى بها الرسول القوم ويجعلها آية

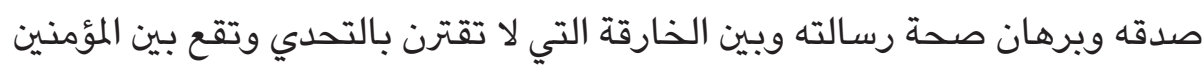

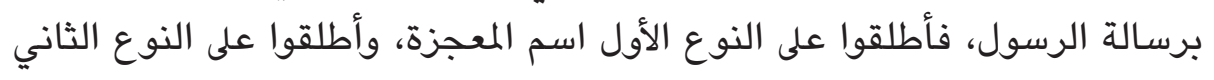

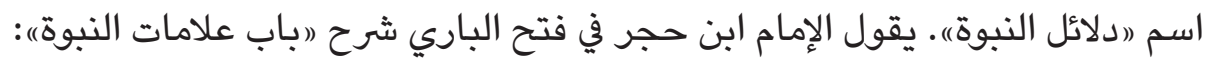

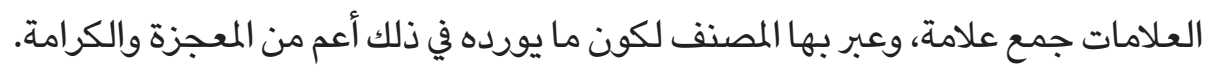

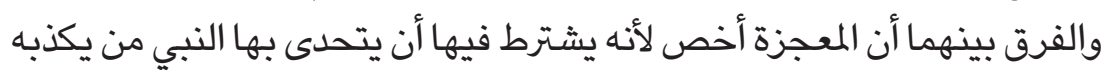

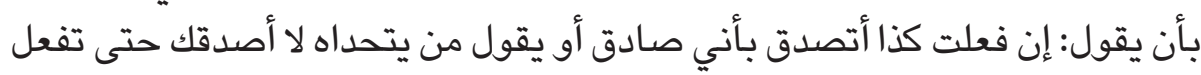

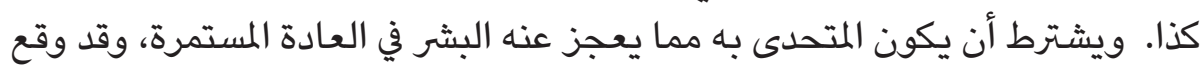

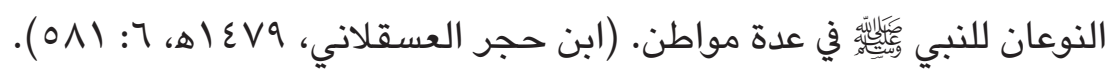

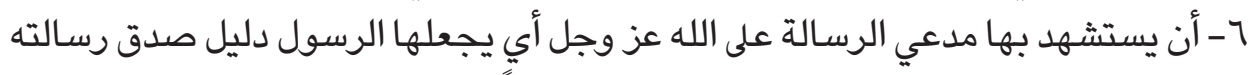

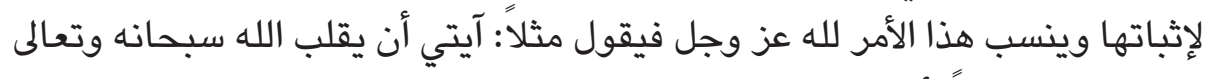

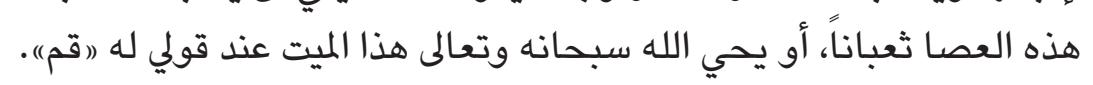

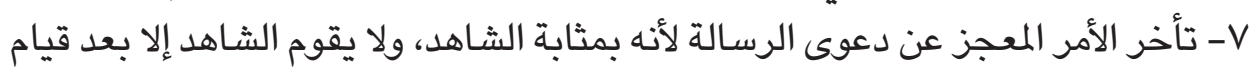

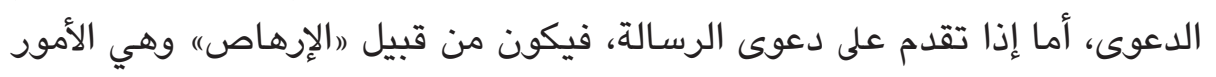

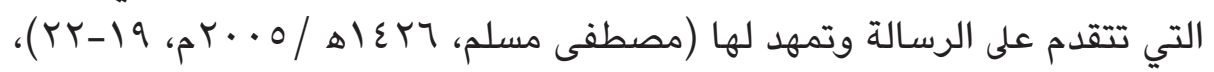

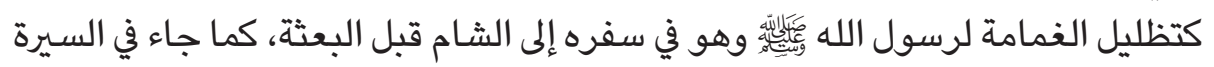

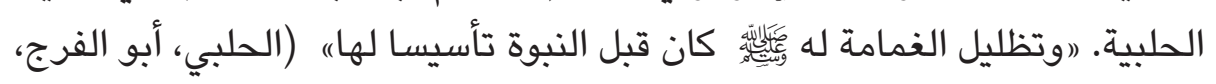

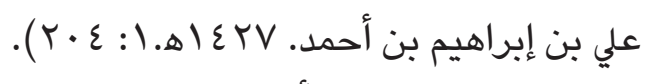

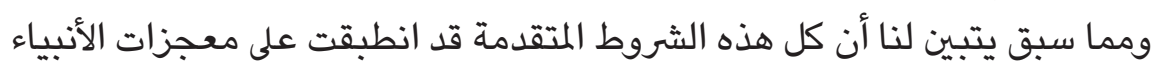

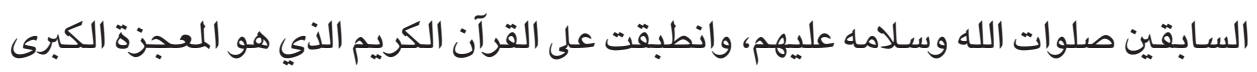

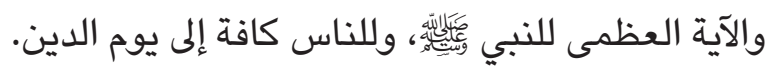


والذي يريد هذا البحث بيانه والتفصيل فيه ما اختصت به هذه المعجزة وتميزت عن

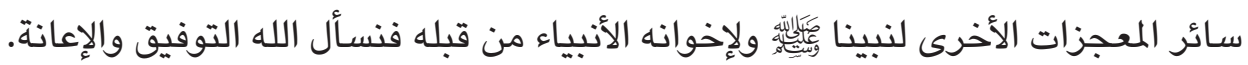

\section{المبحث الثاني: إنها معجزة عقليتتباقيتً}

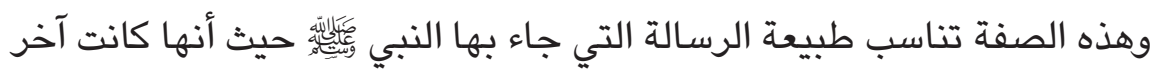
الرسالات وللناس كافة إلى يوم الدين، ولذلك يقول الإمام السيوطي رحمه اللئه الله في الإتقان

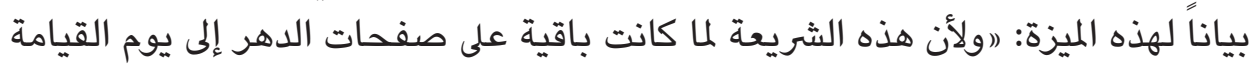

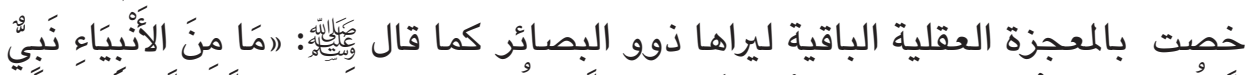

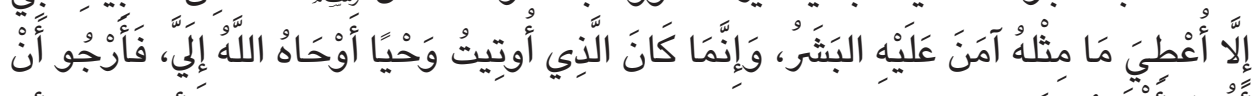

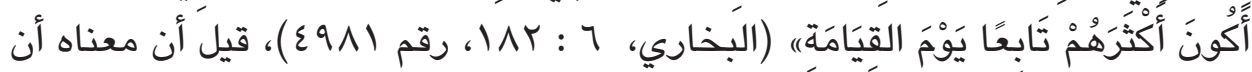

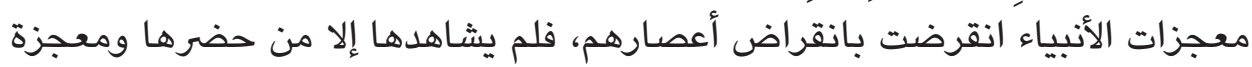

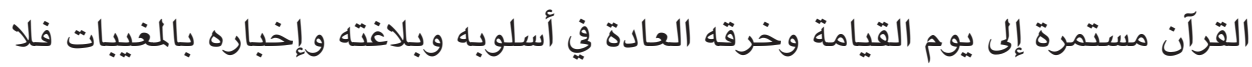

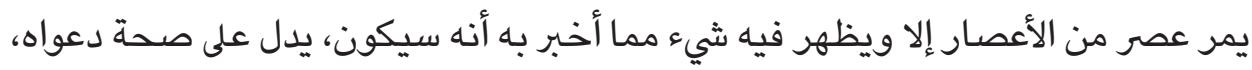

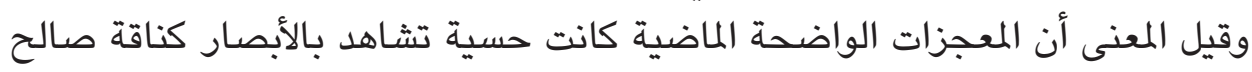

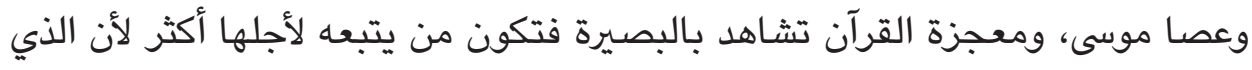
يشاهد بعين الرأس ينقرض بانقراض مشاهده والذي يشاهد بعين العقل باق يشاهده

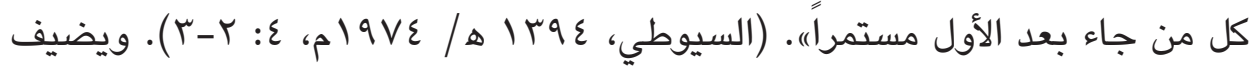

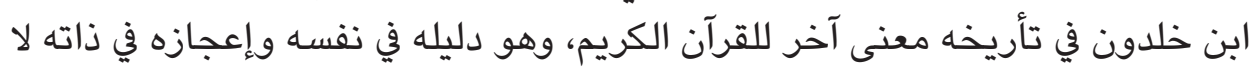

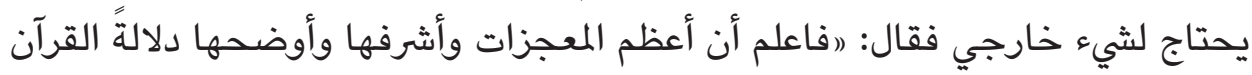

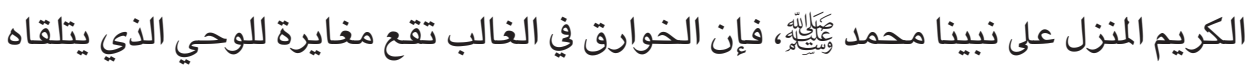

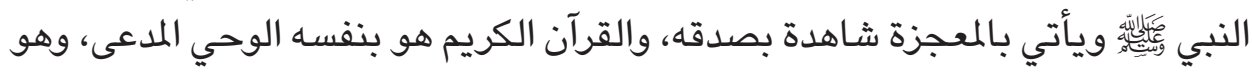

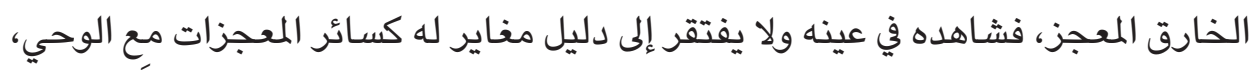

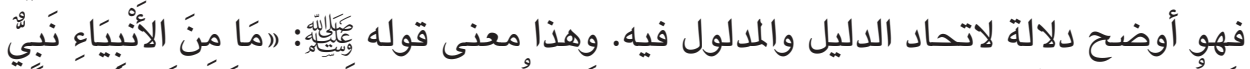

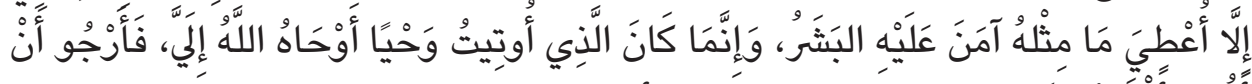

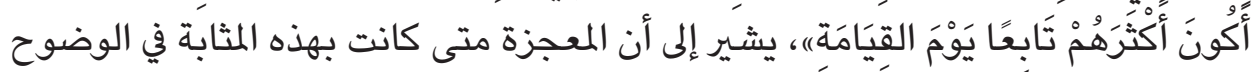

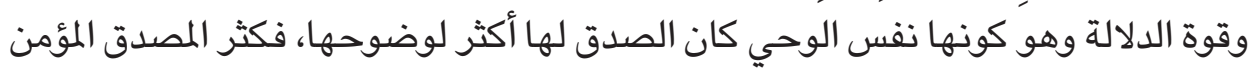

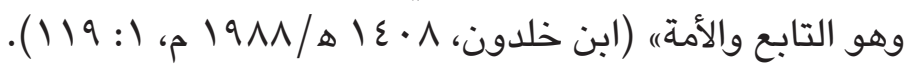

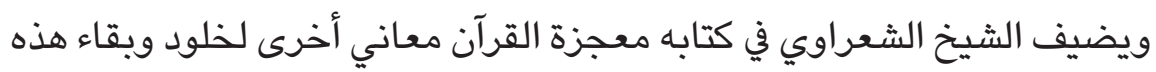
المعجزة فيقول: إذا نظرنا إلى المعجزات السابقة، وجدنا هذه المعجزات فعل من أفعال الله 
وفعل الله من الممكن أن ينتهي بعد أن يفعله الله، البحر انشق لموسى ثم عاد لطبيعته، النار

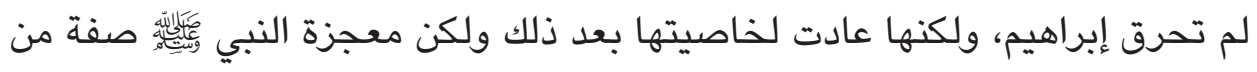

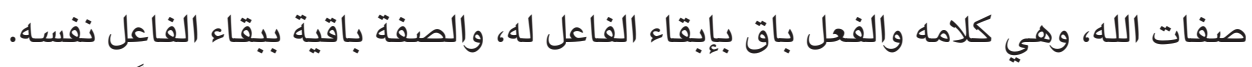

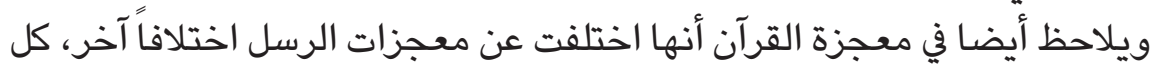

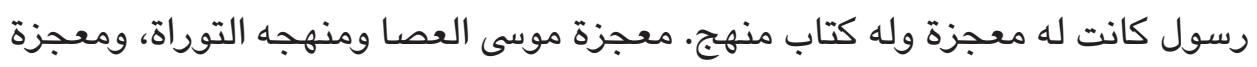

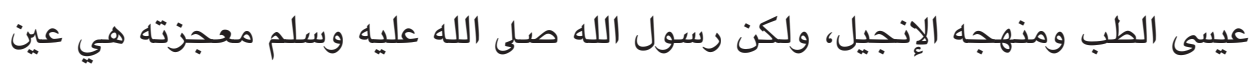

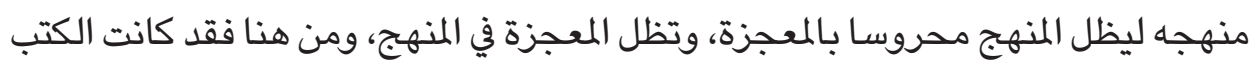

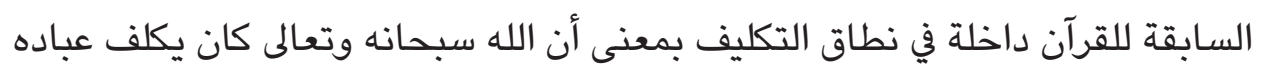

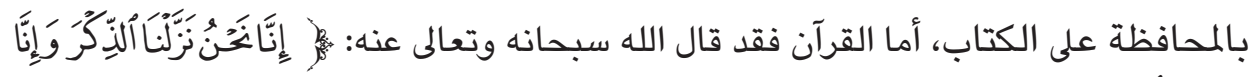

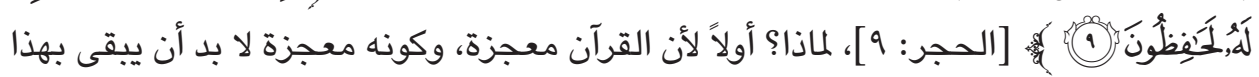
النص، وإلا ضاع الإعجاز. وثانيا: لأن الله جرب عباده في الحفاظ على الكتب السابقة فنسوا حظاً مما ذكروا به.

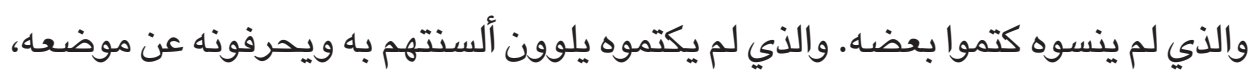

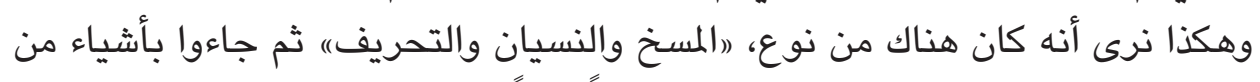

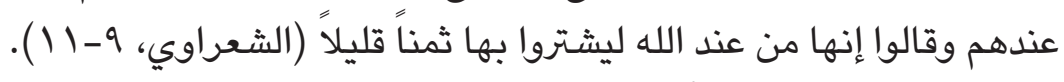

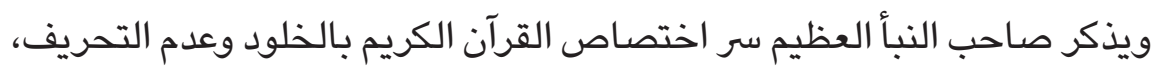

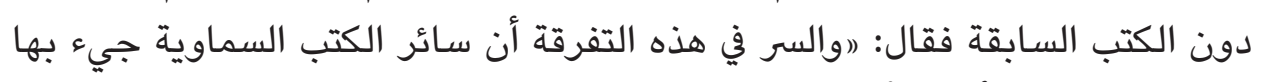

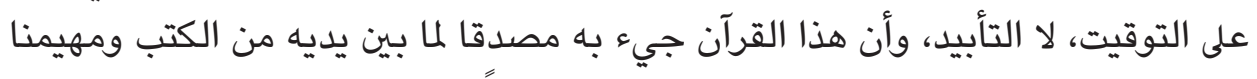

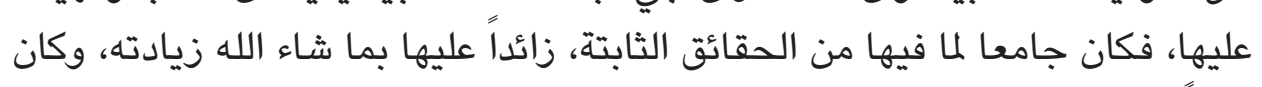

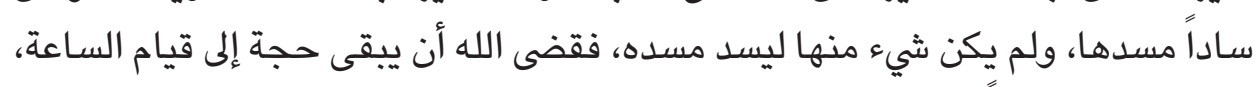

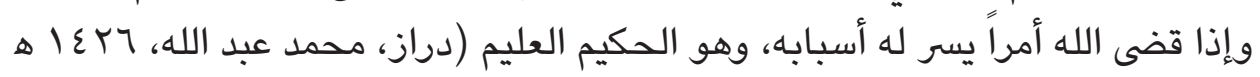

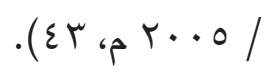

ومما سبق نخلص إلى أن القرآن الكريم معجزة اختصت بالخلود والبقاء. وهي

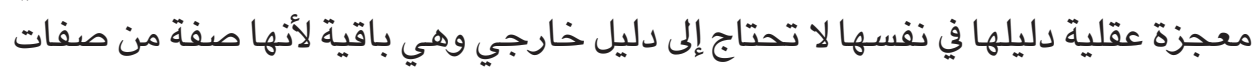
الباقي جل جلاله وهي من كلامه.

\section{المبحث الثالث: تعدد وتجدد وجوه الإعجاز فيها}

وهذه الصفة تميز بها القرآن الكريم كمعجزة فلم يكن الإعجاز فيه على وجه واحد ودئ

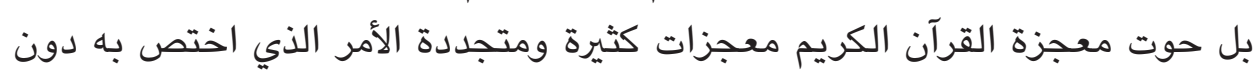


معجزات الأنبياء السابقين. وفي ذلك يقول القاضي عياض رحمه الله عن هذه المعجزات:

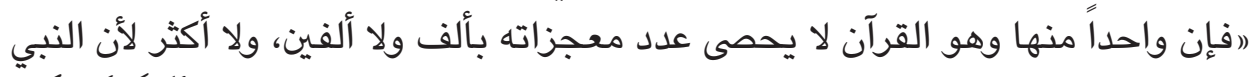

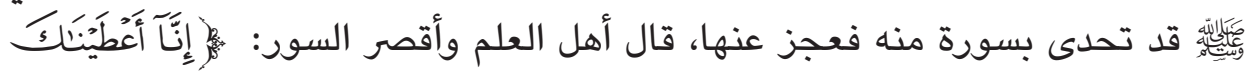

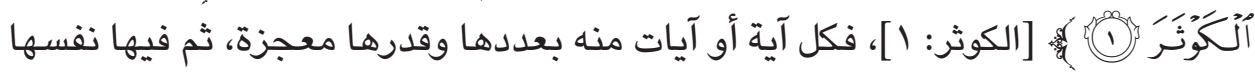

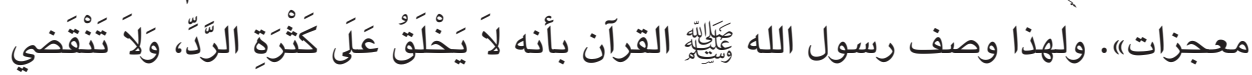

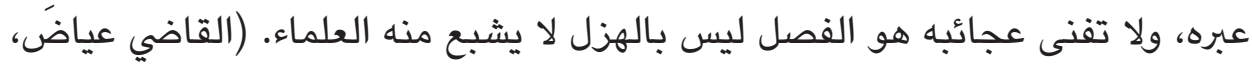

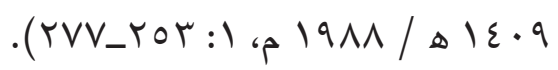

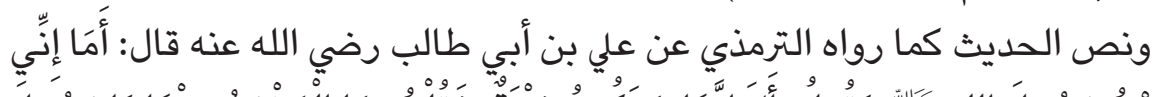

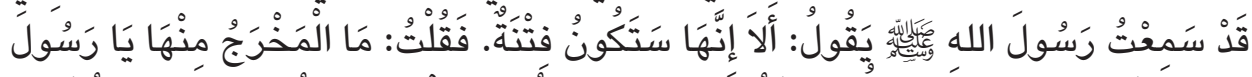

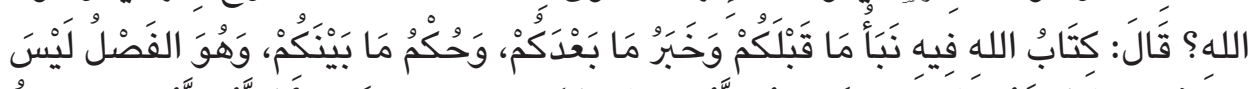

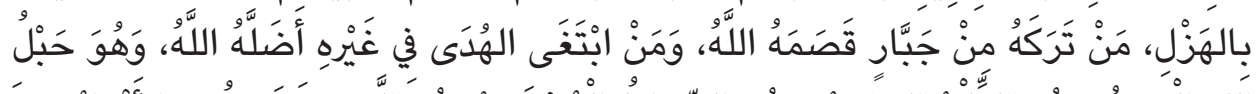

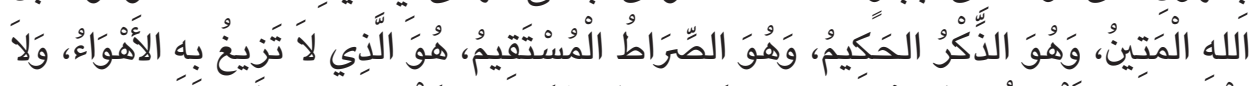

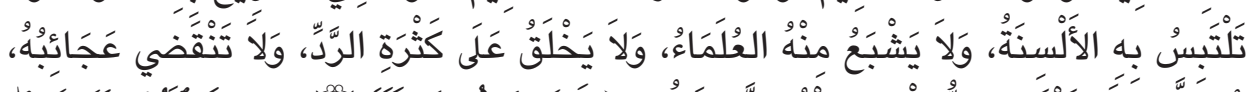

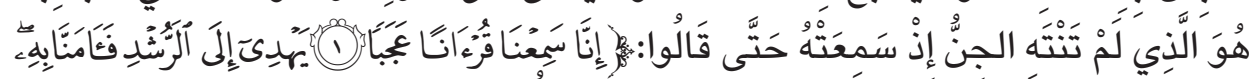

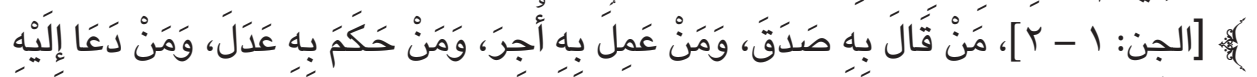

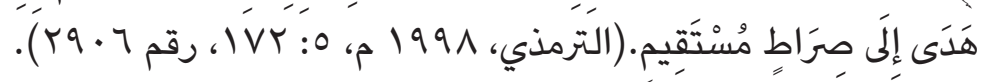

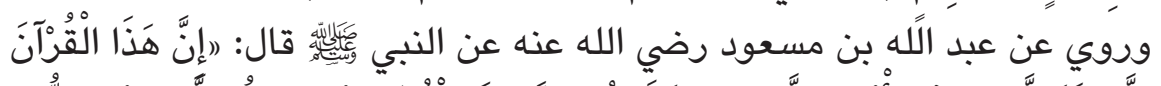

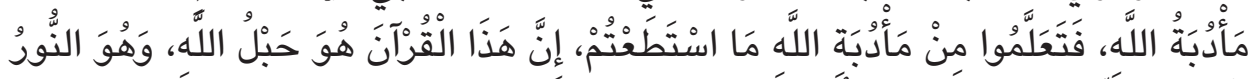

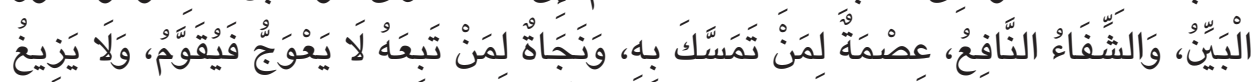

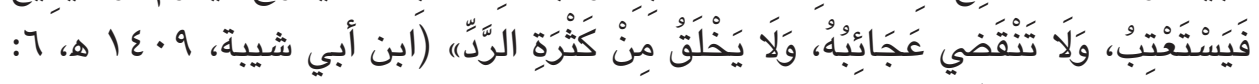

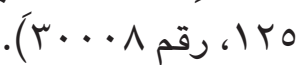

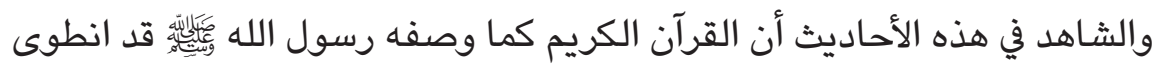

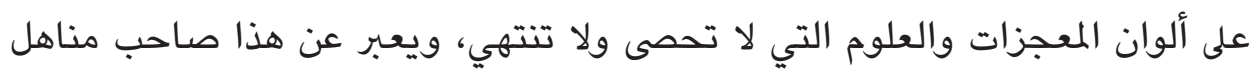

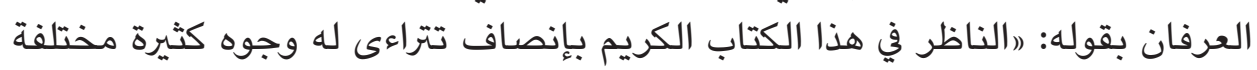

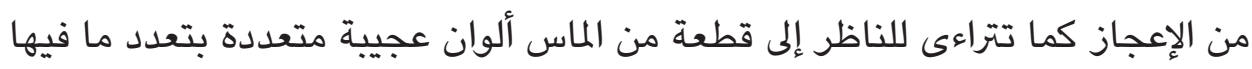

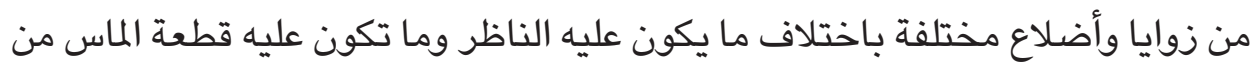
الأوضاع (الزرقاني، r ب: r०9). 
وخلاصة القول إن معجزة القرآن الكريم قد حوَت وجوها متعددة ومتجددة من

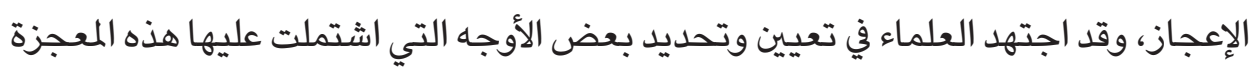

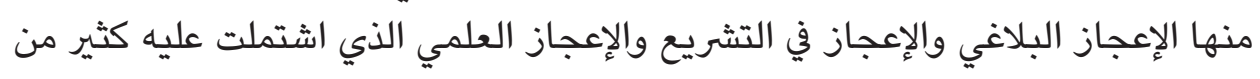
الآيات الكونية في القرآن الكريم، وستبقى هنالك وجوه لم يحن الإعن الوقت لمعرفتها واكتشافها

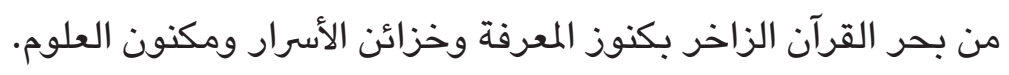

\section{المبحث الرابع: كونها حافظت وشاهدة لمعجزات الأنبياء}

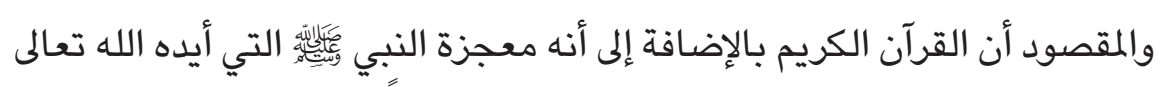

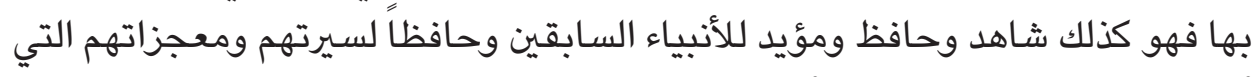

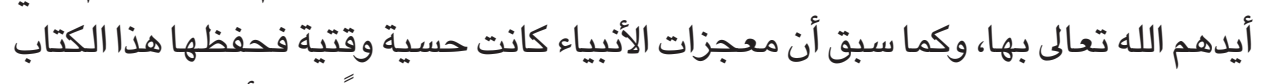

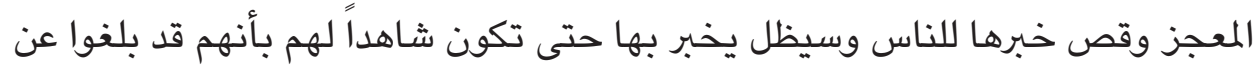

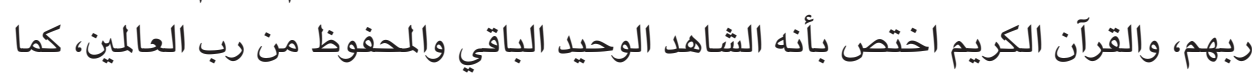

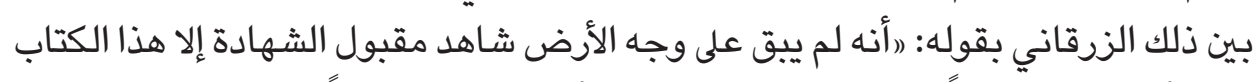

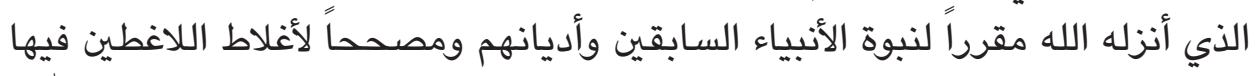

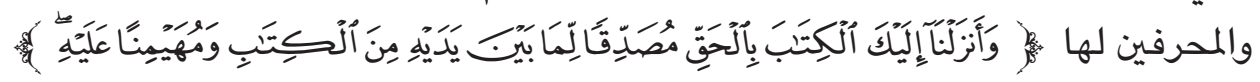

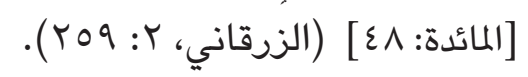

وقد جاء في تفسير هذه الآية: ولما ذكر سبحانه وتعالى الكتابين ذكر ختامهما وتمامهما

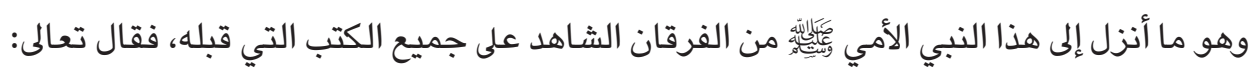

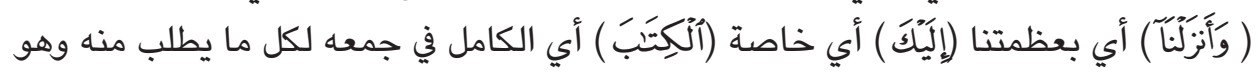

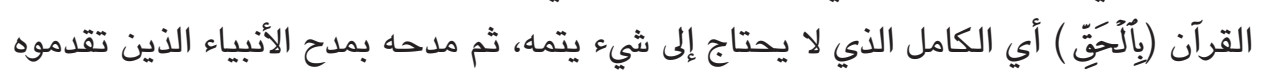

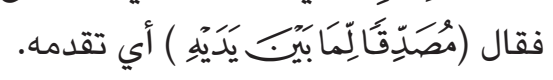

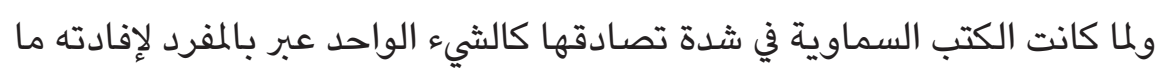

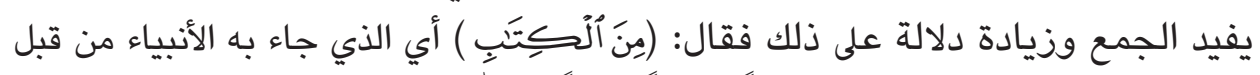

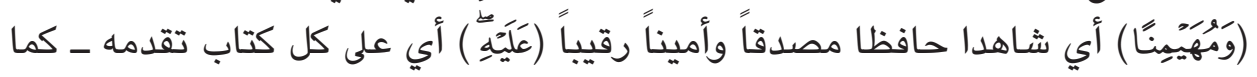

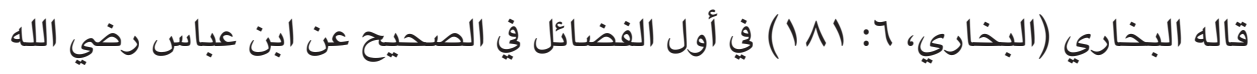

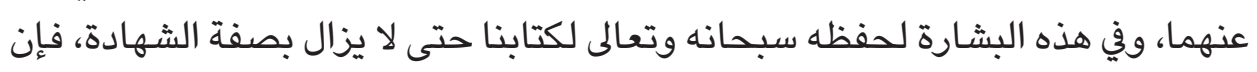

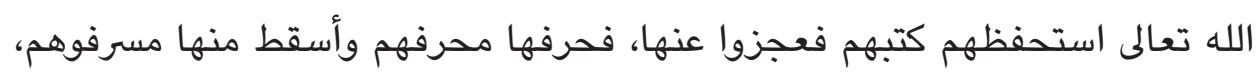

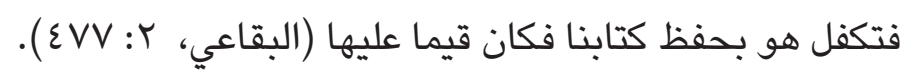

el Harakah Jurnal Budaya Islam Vol. 19 No.1 Tahun 2017 
وجاء في مفاتح الغيب "إنما كان القرآن مهيمناً على الكتب، لأنه الكتاب الذي لا

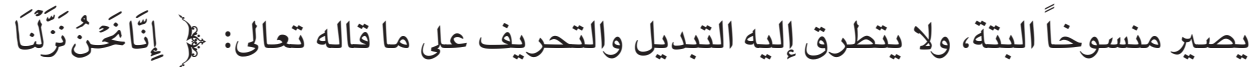

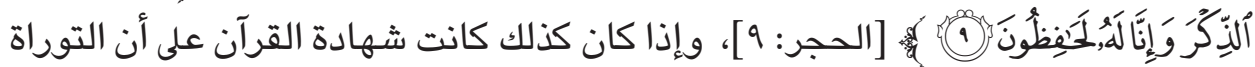

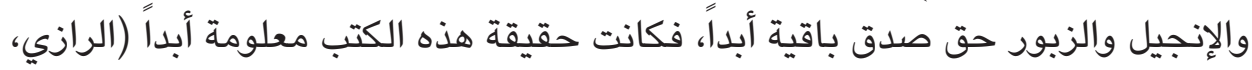

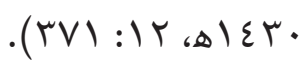

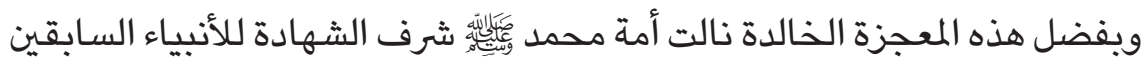

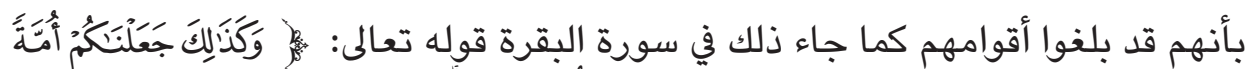

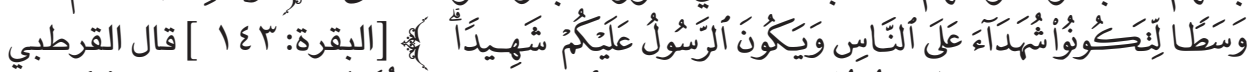

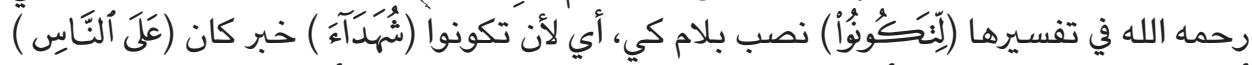

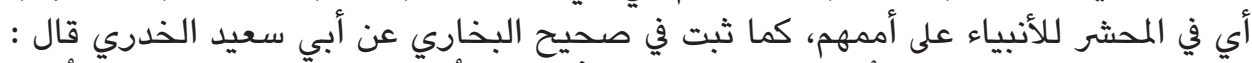

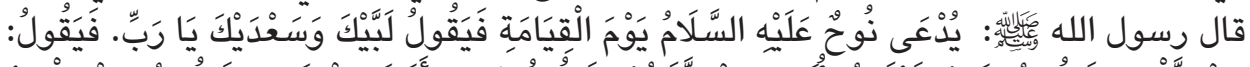

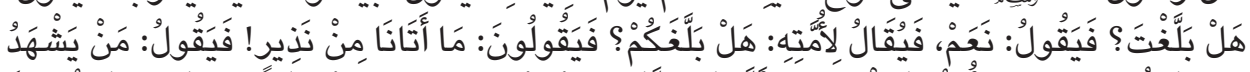

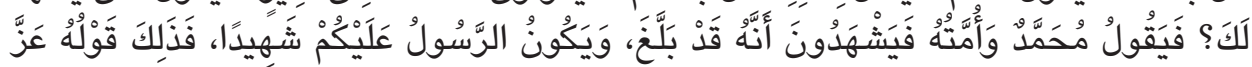

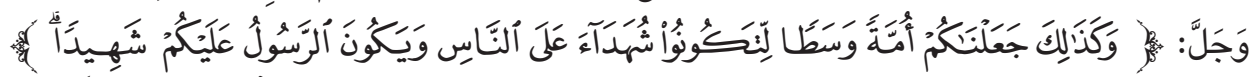

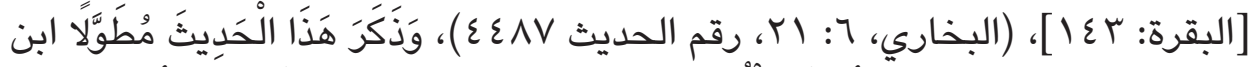

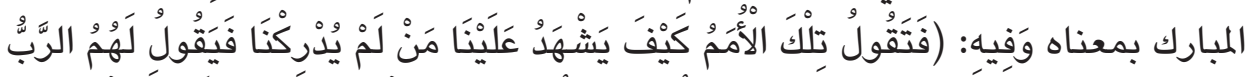

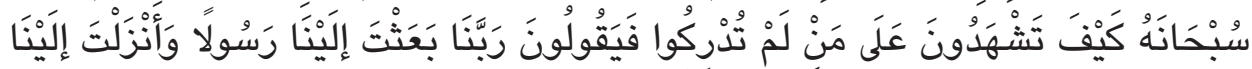

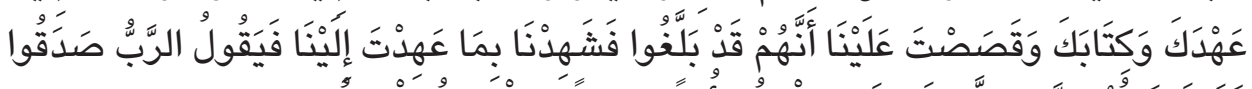

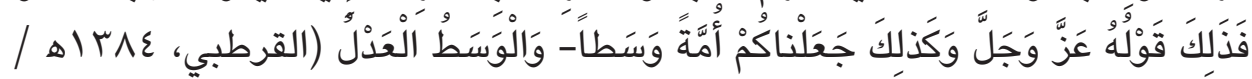

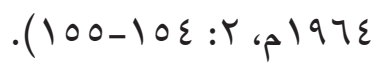

\section{المبحث الخامس : إنها معجزة للثقلين}

وهذه الصفة تميزت بها معجزة القرآن الكريم دون معجزات الأنبياء السابقين

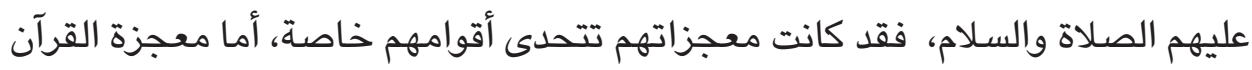

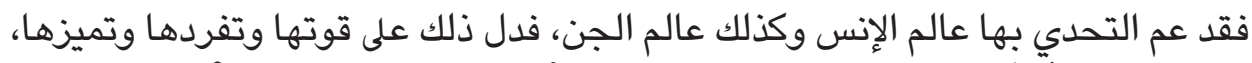

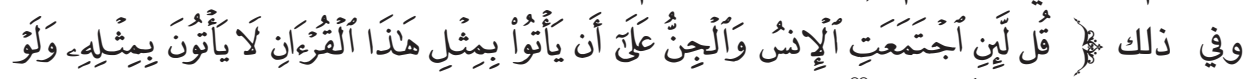

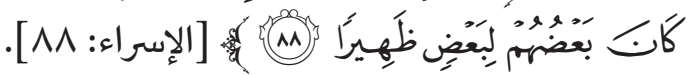

$$
\begin{aligned}
& \text { و إليك أقوال المفسرين في بيان هذه الآية: }
\end{aligned}
$$

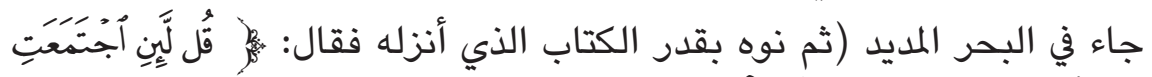

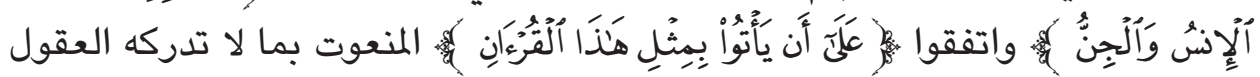




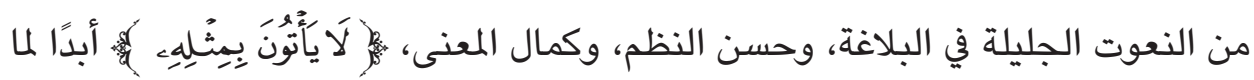

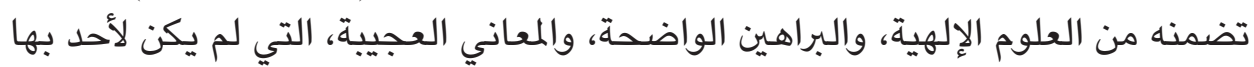

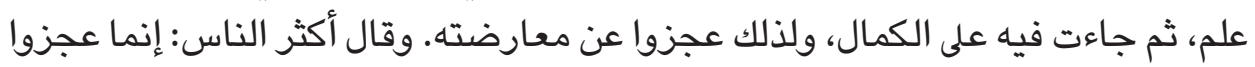

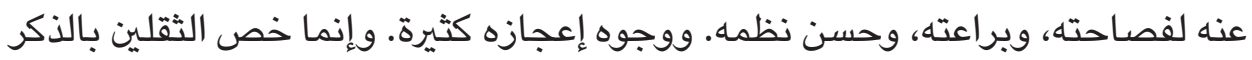

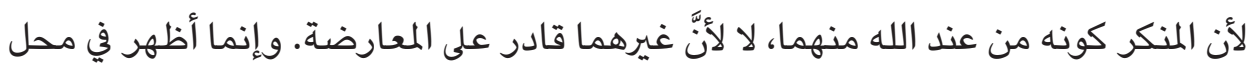

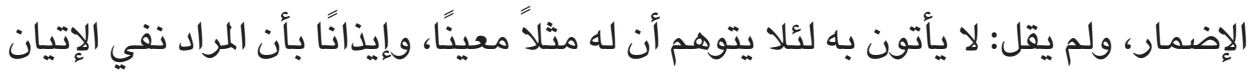

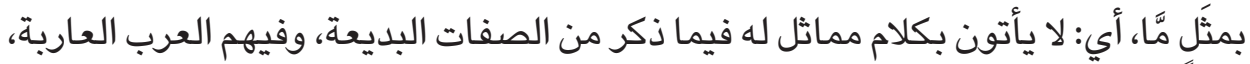

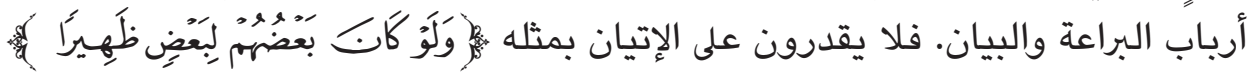
أي: ولو تظاهروا وتعاونوا على الإتيان بمثله ما قدروا. وهو عطف على على مقدّر، أي: لا يأتون

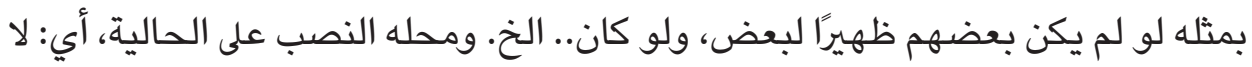

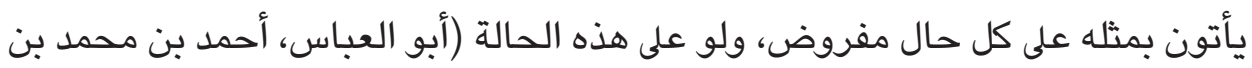
المهدي بن عجيبة الحسني، تحقيق: أحمد عبد الله القرشي رسلان.

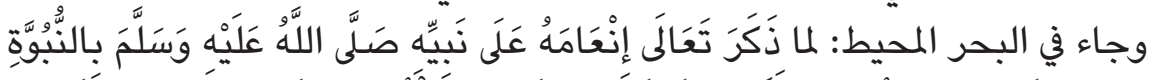

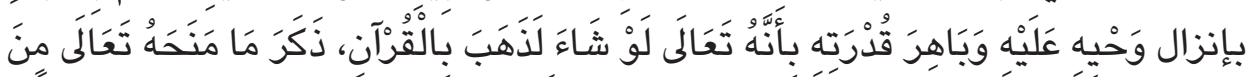

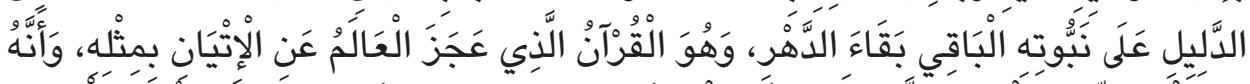

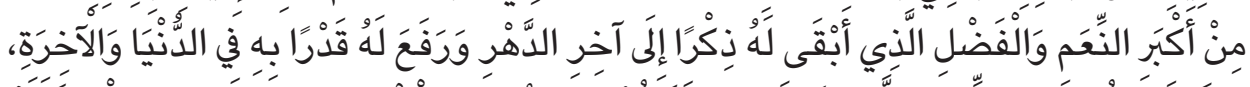

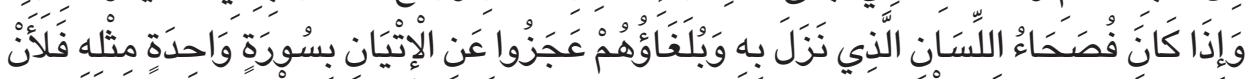

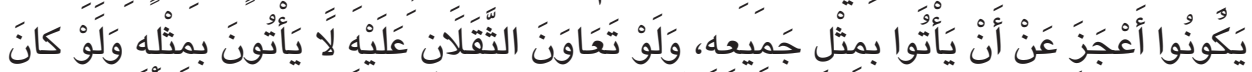

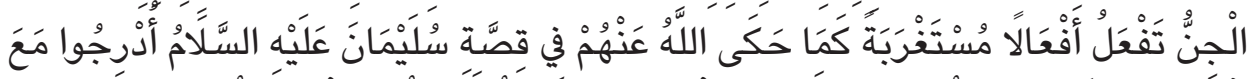

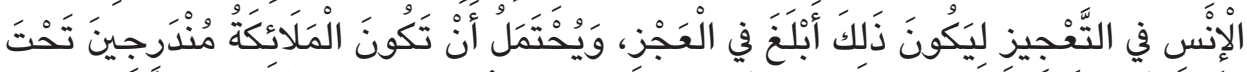

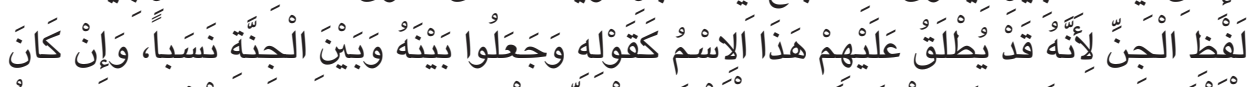

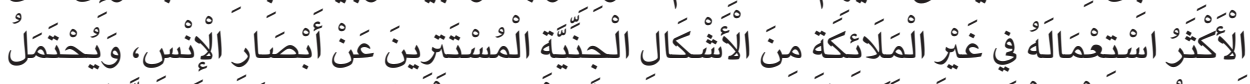

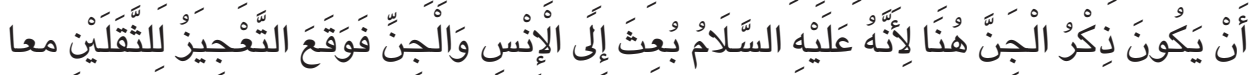

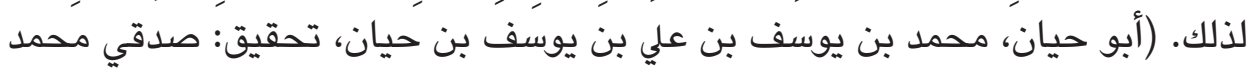

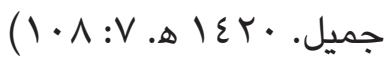

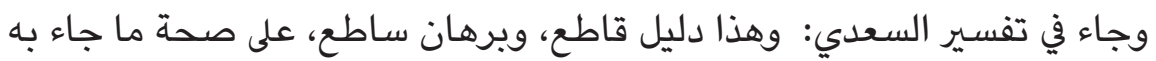

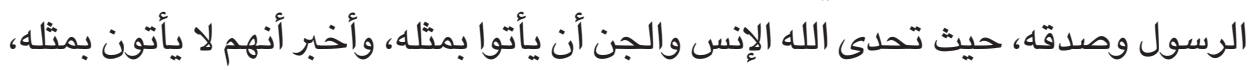
ولو تعاونوا كلهم على ذلك لم يقدروا عليه. 
ووقع كما أخبر الله، فإن دواعي أعدائه المكذبين به، متوفرة على رد ما جاء به بأي

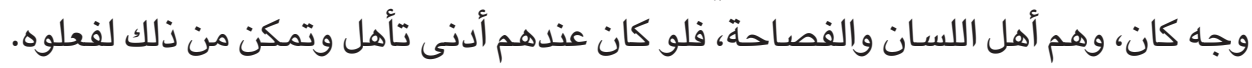

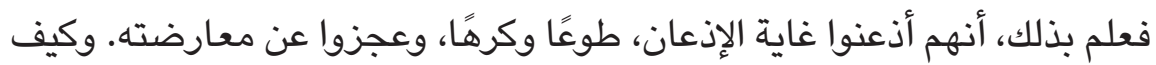

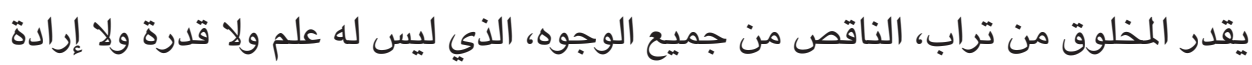

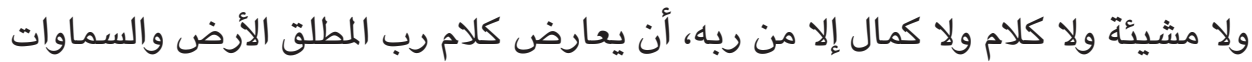

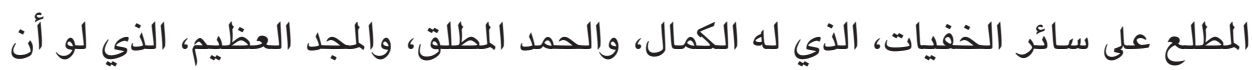

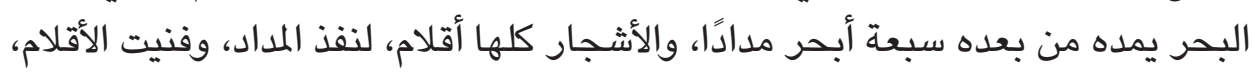
ولم تنفد كلمات الله.

فكما أنه ليس أحد من المخلوقين مماثلا لله في أوصافه فكلامه من أوصافه، التي

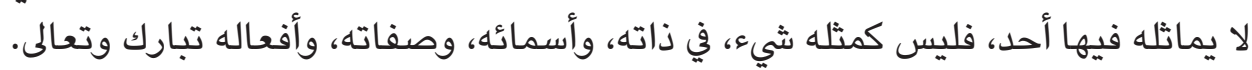

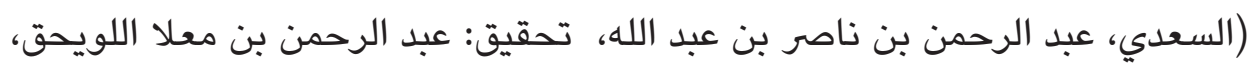

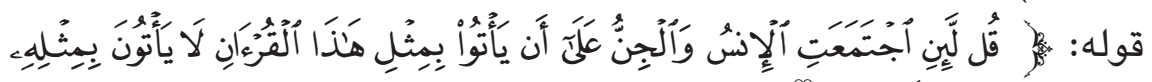

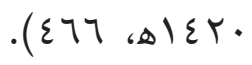

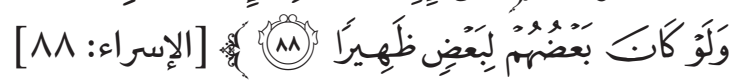

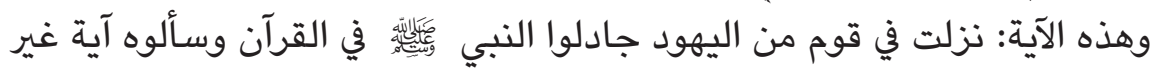

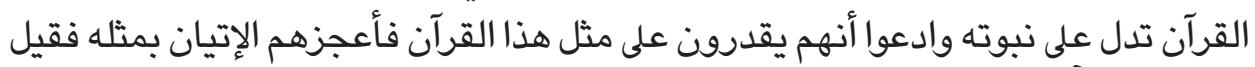

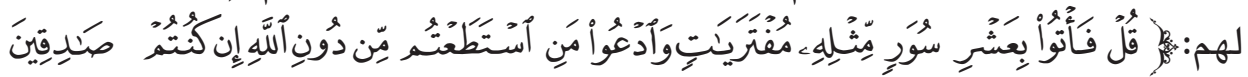

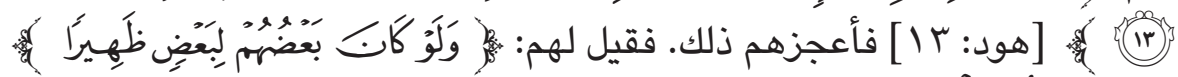

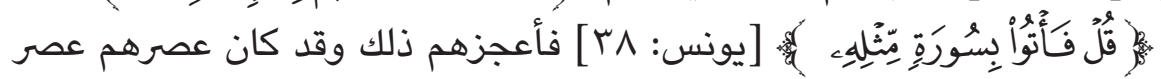
فصاحة ويلاغة. وقيل: إن الخطاب بذلك لقريش وهم الذي عجزوا عن الإتيان بسورة ويعشر سور

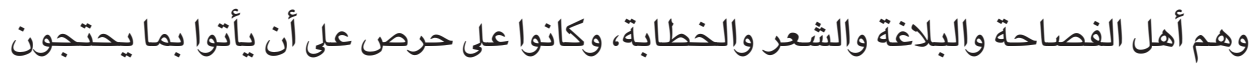

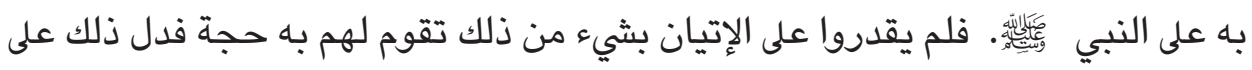

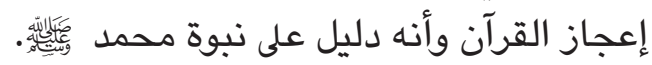

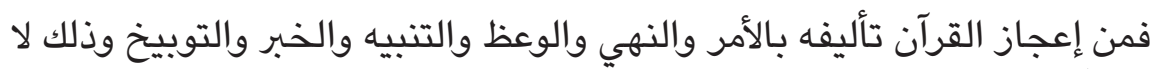

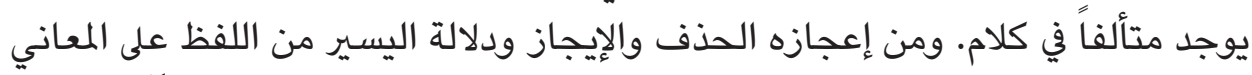

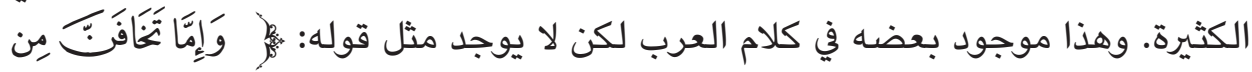




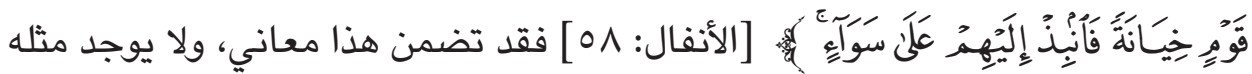
في كلام العرب بهذه الفصاحة ومثله كثير في القرآن. ومعنى الإيجاز هو إظهار المعاني الكثيرة باللفظ القليل ومن إعجازه ما فيه من

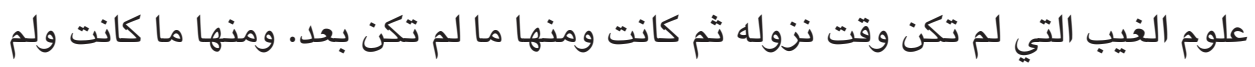

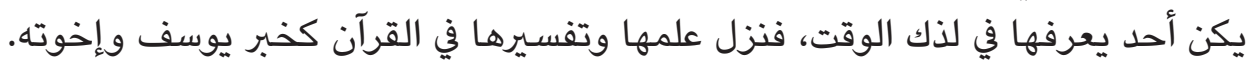

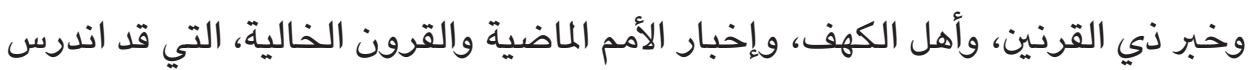

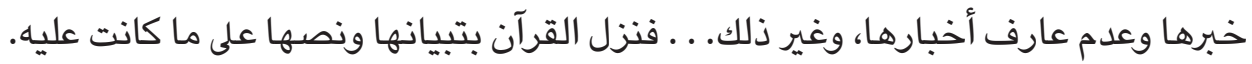

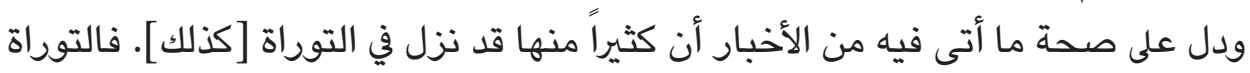

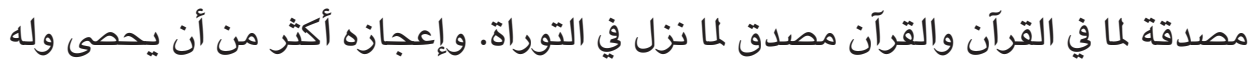

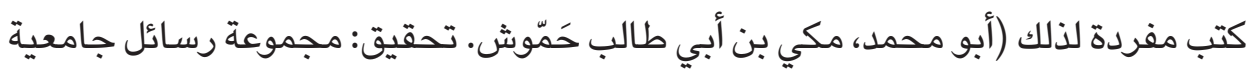

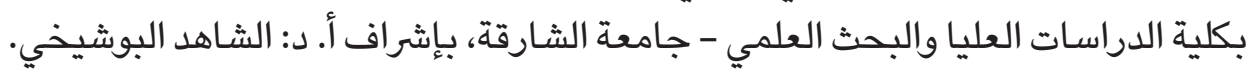

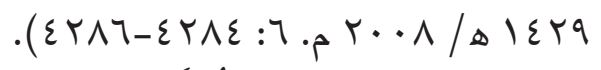

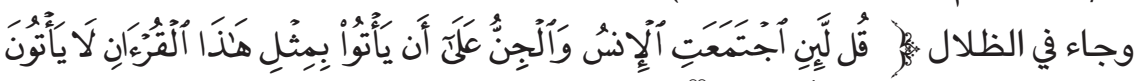

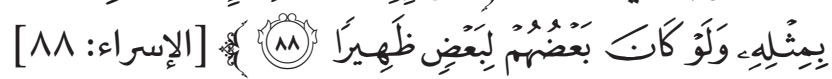

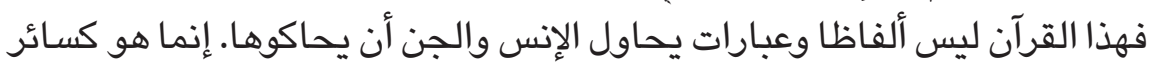

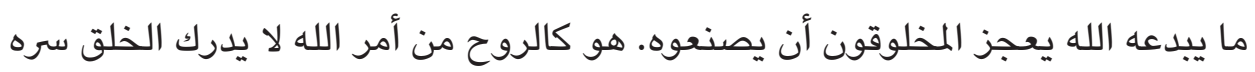
الشامل الكامل، وإن أدركوا بعض أوضدون ألمافه وخصائصه وآثاره.

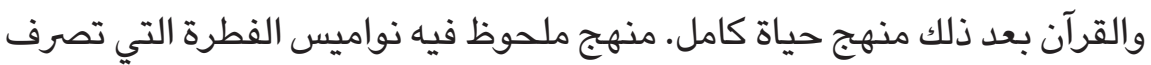

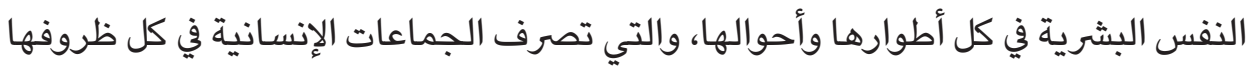

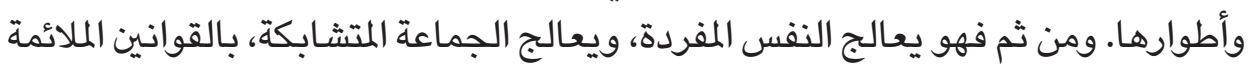
للفطرة المتفلغلة في وشائجها ودروبها ومنون وفنياتها الكثيرة.

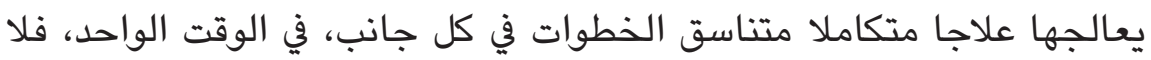

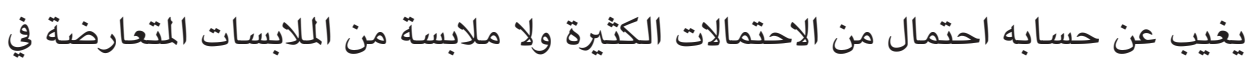

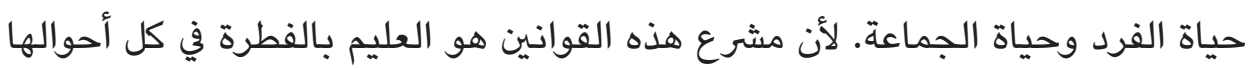
وملابساتها المتشابكة. أما النظم البشرية فهي متأثرة بقصور الإنسان وملابسات حياته. ومن ثم فهي تقصر عن الإحاطة بجميع الاحتمالات في الوقت الواحد وقد تعالج ظاهرة فردية أو أو اجتماعية الإنية بدواء يؤدي بدوره إلى بروز ظاهرة أخرى تحتاج إلى علاج جديد! إن إعجاز القرآن أبعد الإحة 
مدى من إعجاز نظمه ومعانيه، وعجز الإنس والجن عن الإتيان بمثله هو عجز كذلك عن

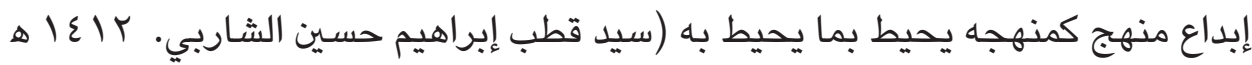
.) (rY乏Q-rYO.: : 。

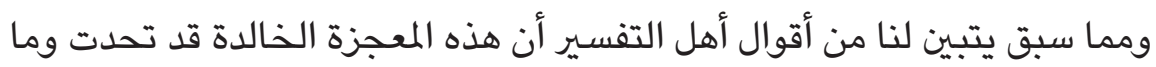
زالت تتحدى الإنس والجن إلى قيام الساعة ,وقد ثبت عجزهم وضعفهم عن الإتيان بمثلها

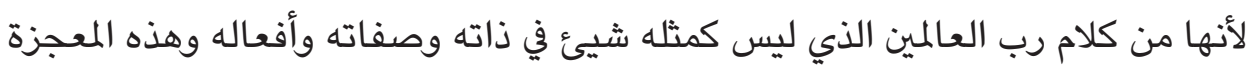
صفة من صفاته ,ودل كذلك على صفة متميزة تضاف إلى صفاتها وخصائصها التي

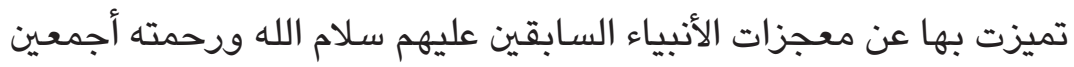

\section{المبحث السادس: آثارها على ثقافت الشعوب}

وهذه من الخواص التي تميزت بها معجزة القرآن الكريم من بين سائر المعجزات،

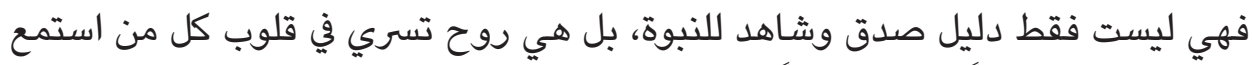

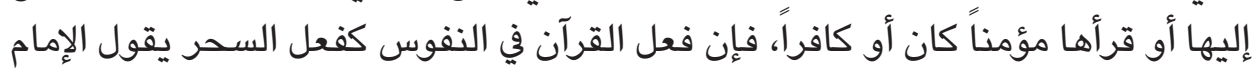

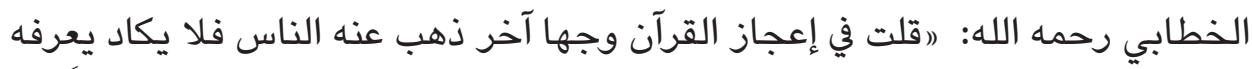

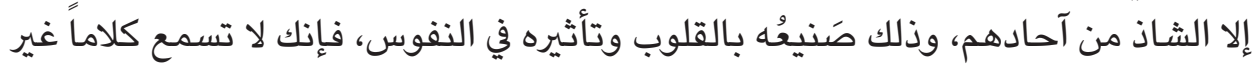

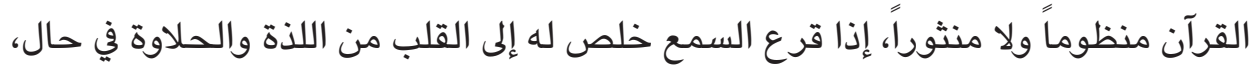

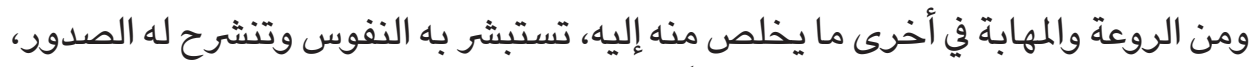
حتى إذا أخذت حظها منه عادت مرتًاعةً (أي فزعة) قد عراها الوجيب المتئ (أي الاضطراب)

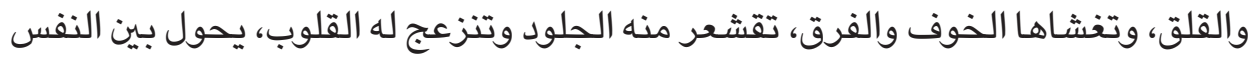

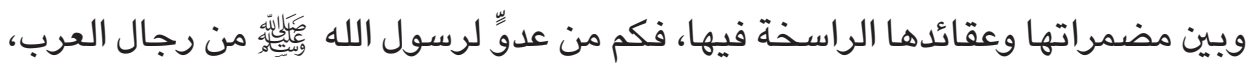

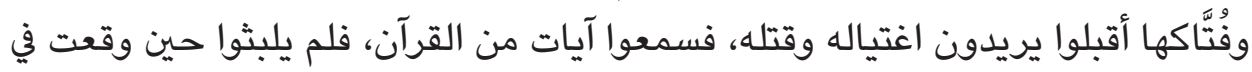

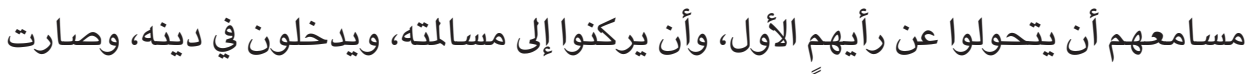
عداوتهم موالاة، وكفرهم إيماناً.

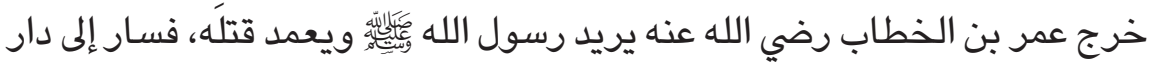

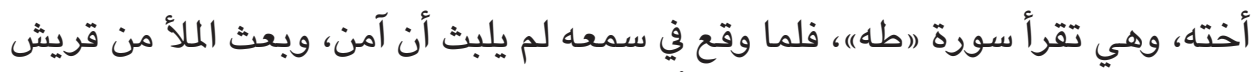

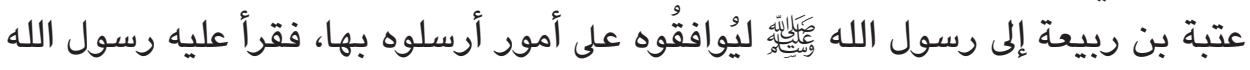

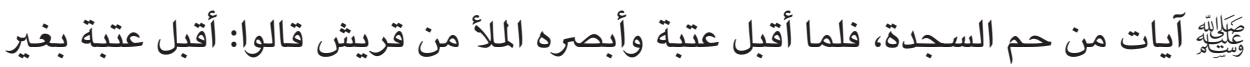

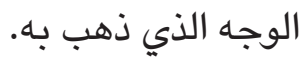




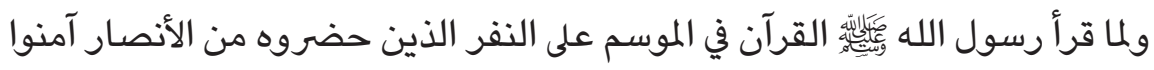

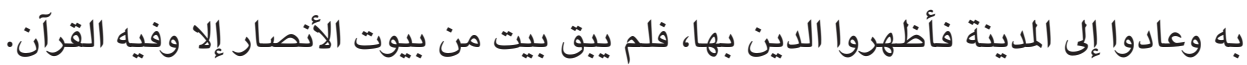

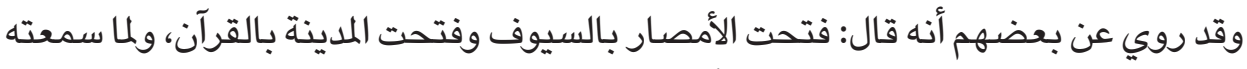

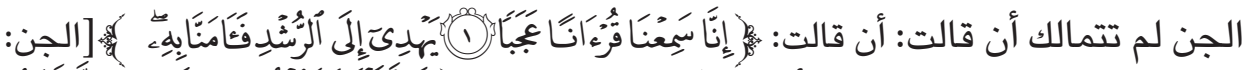

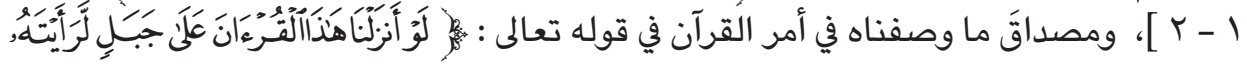

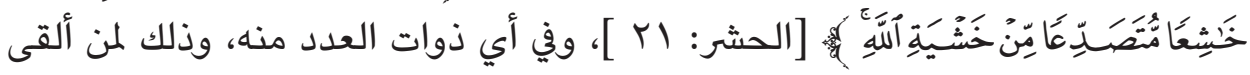

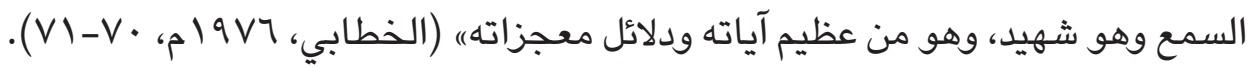

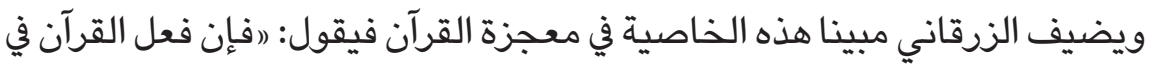

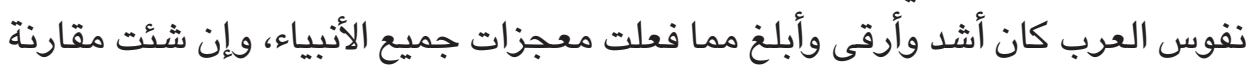

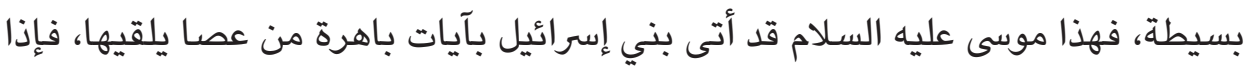

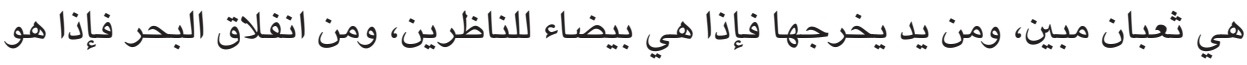

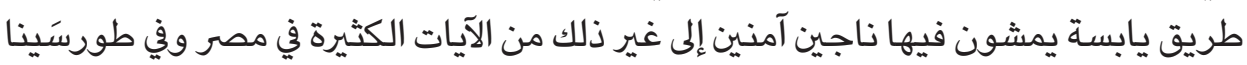

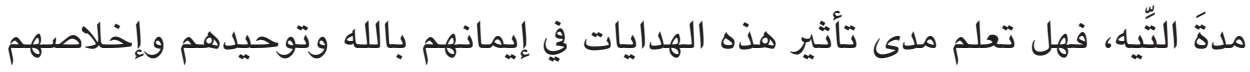

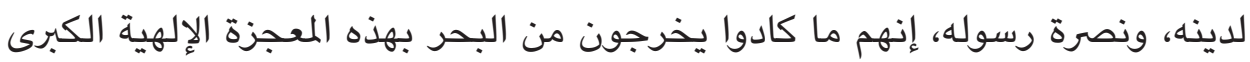

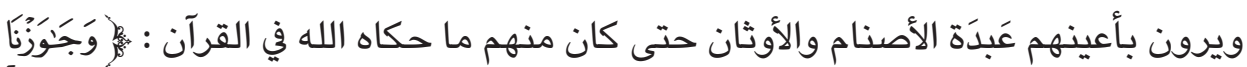

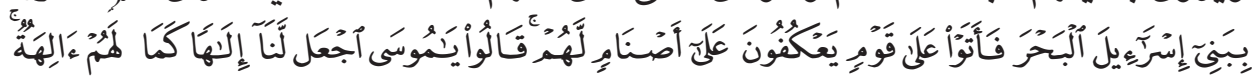

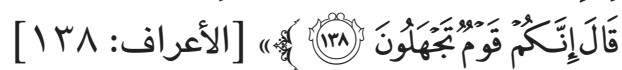

ثم يقول: „لكن القرآن الكريم وحده هو الذي نفخ الإيمان في الكبار والصغار الصار نفخاً

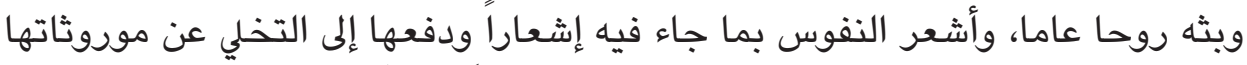

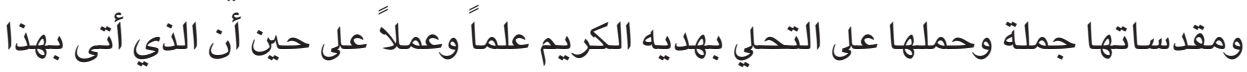

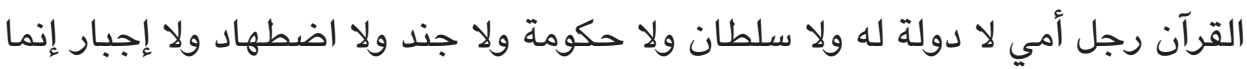

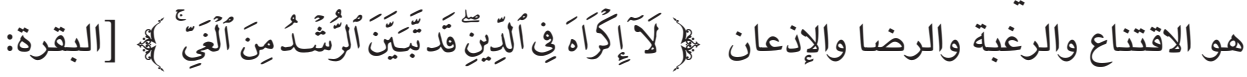

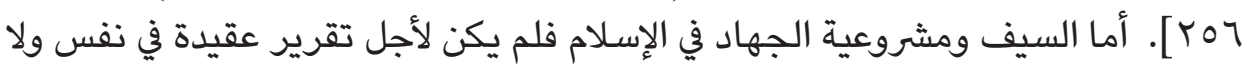

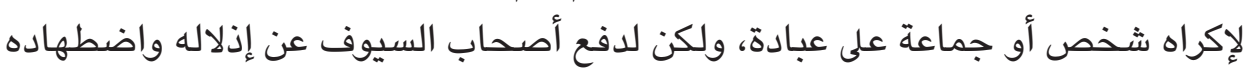
وحملهم على أن يتركوا دعوة الحق حرة طليقة حتى لا تكون فتنة ويكون الدين لله

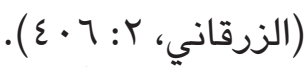

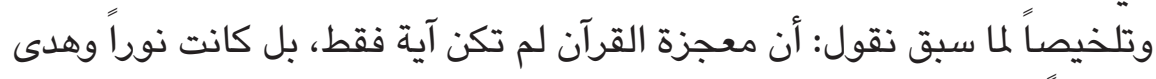

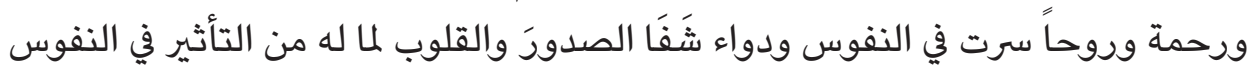


والأبدان معاً، فكانت هذه من الخصائص الفريدة لمعجزة القرآن والتي تميزت بها عن

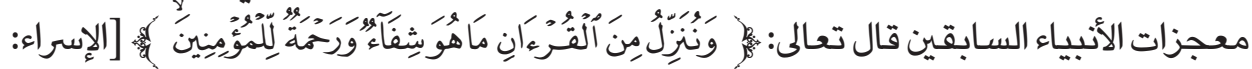
rAr

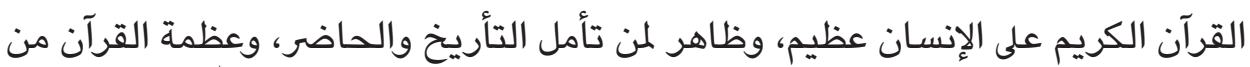

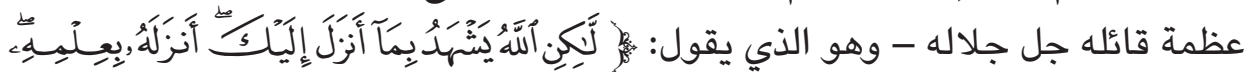

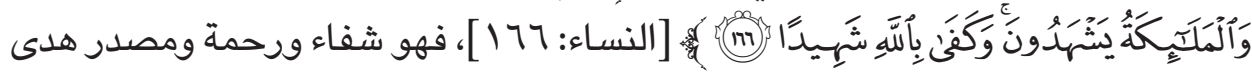

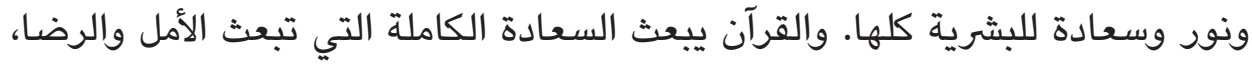
وتثمر السكينة والاطمئنان وتحقق الأمن الروحي الإنسان فيحيا سعيدا هانئًا آمنًا مطمئنًا.

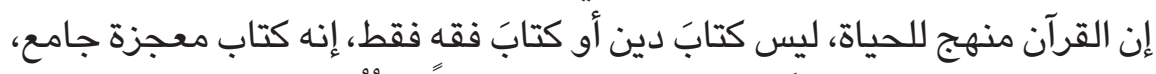

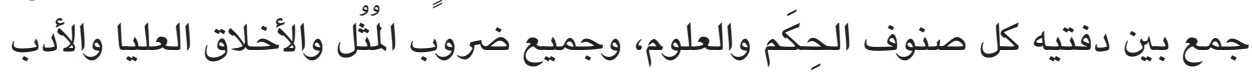

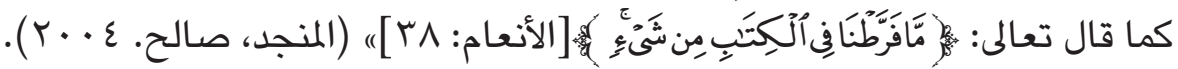

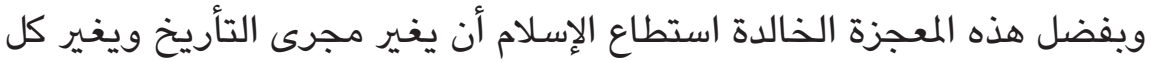

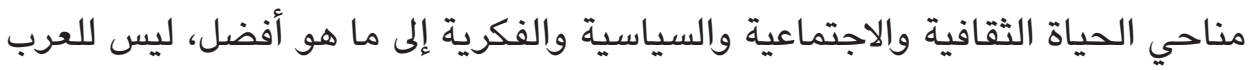

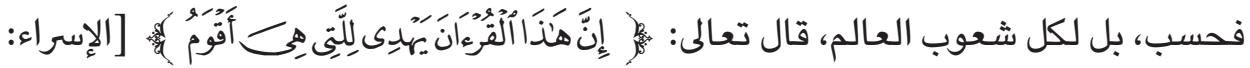

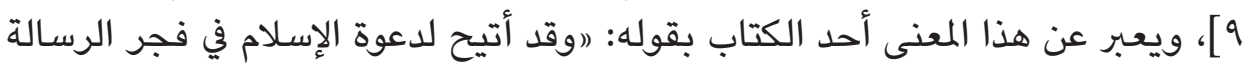

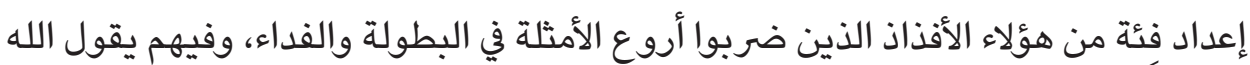

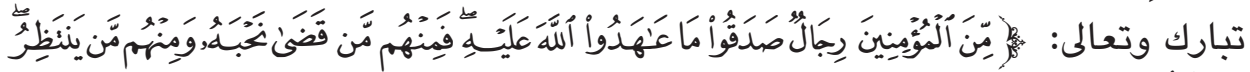

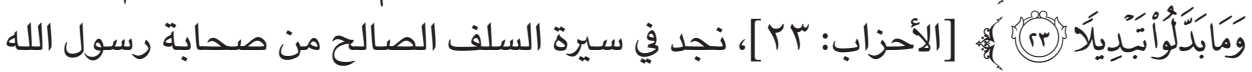

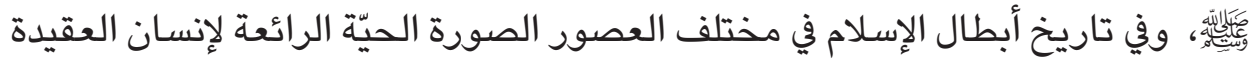
في إيمانه، ويَسَالته، وإخلاصه، ويذله، وصدقه، وصبره، ونشعر ونحن نعيش في ظلالال هذا

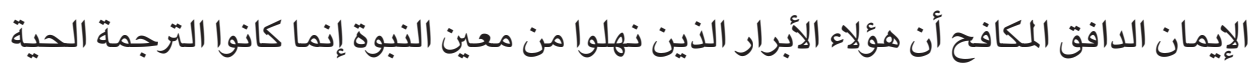

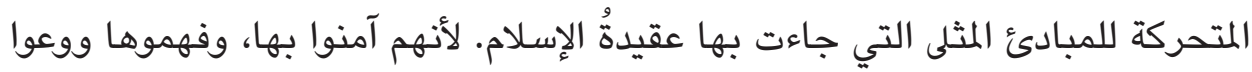

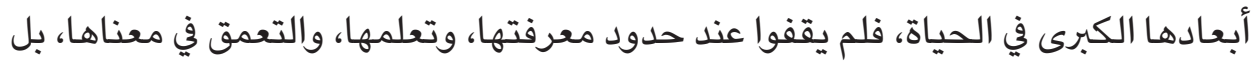

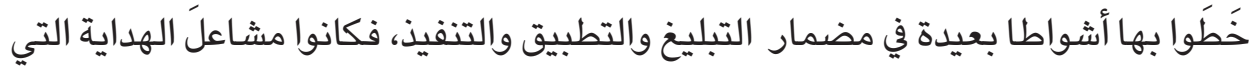

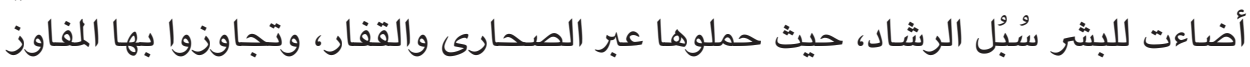

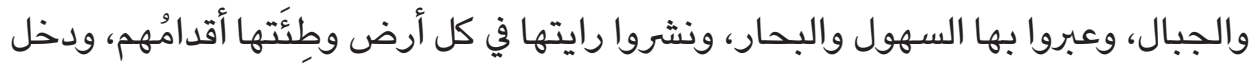

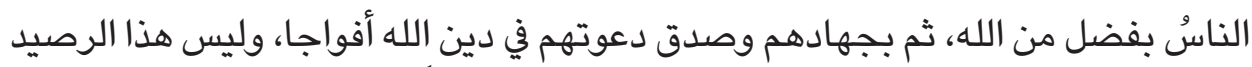

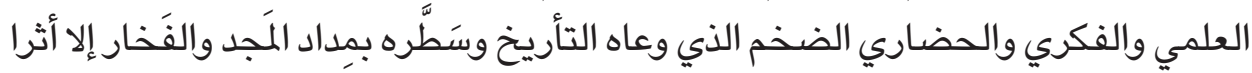


بسيطا من آثار فتح العقيدة النيرة في تلك الأمم والشعوب. ولقد لفتَت هذه الظاهرة العظيمة كثيرا من الباحثين ومؤرخي الحضارة وراصدي نتائجها. وذكر كثير من المنصفين منهم

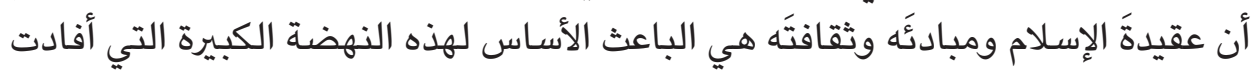

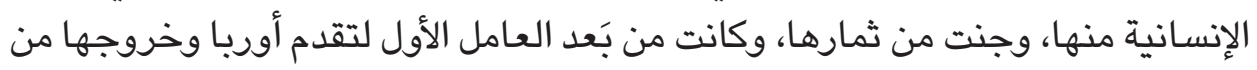

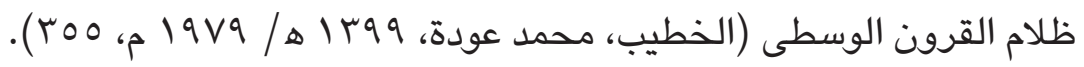

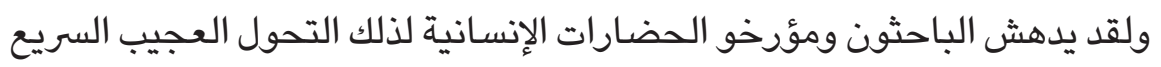

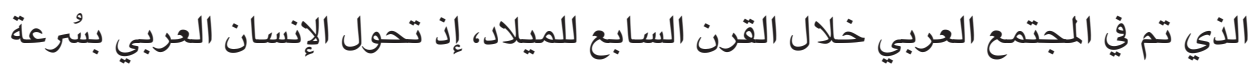

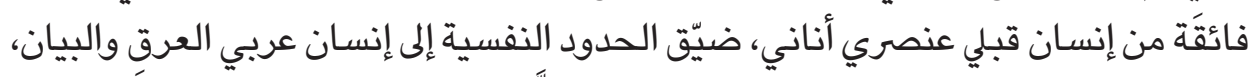

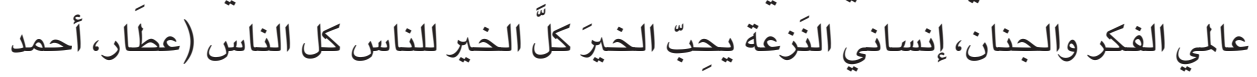

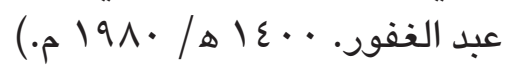
إن ما تشير إليه نصوص القرآن الكريم والسنة من حقائق تتعلق بالأنظمة والظواهر

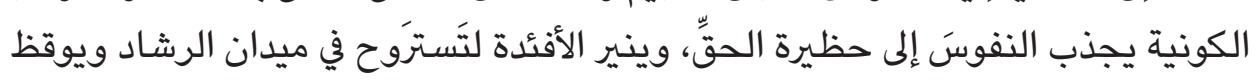

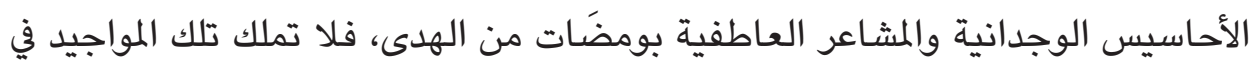

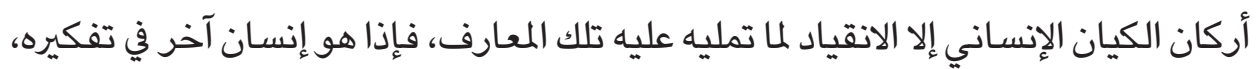
وأعماله، وتقلباته، وشؤونه، وكل حالاته المتعلقة بذاته أو علاقاته مع الآخرين.

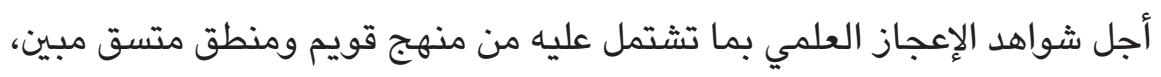

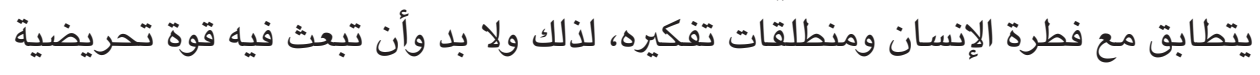

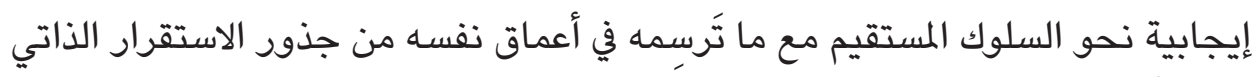

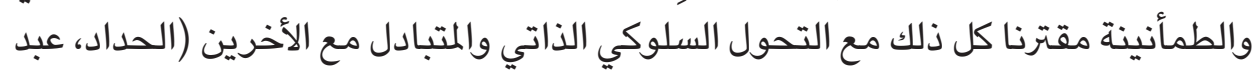

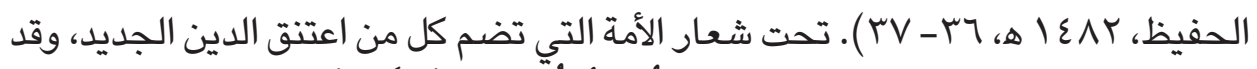

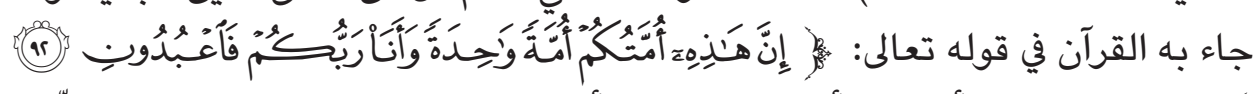

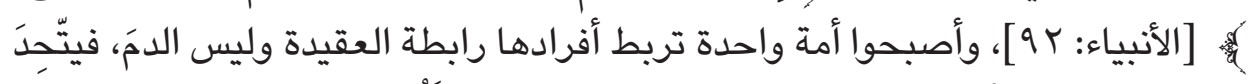

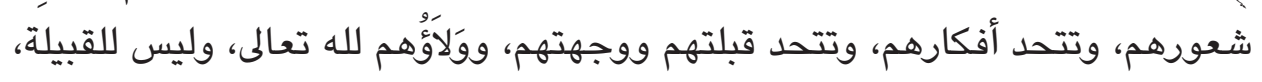

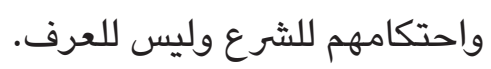
وهذا ما أكده أحد المستشرقين ويدعى ((مونتعري وات) عميد قسم الدراسات العربية

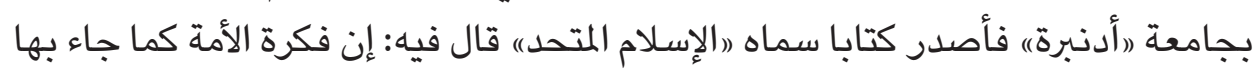

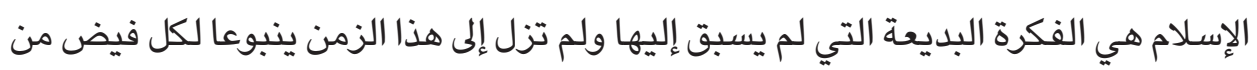

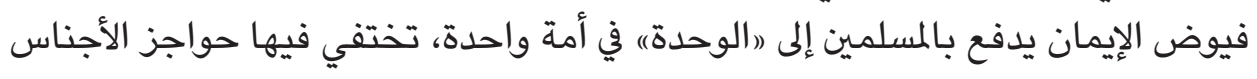


واللغات وعصبيات النسب والسلالة. وقد تفرد الإسلام بخلق هذه الوحدة بين أتباعه،

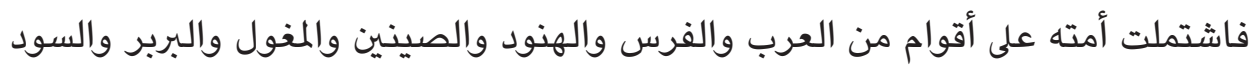

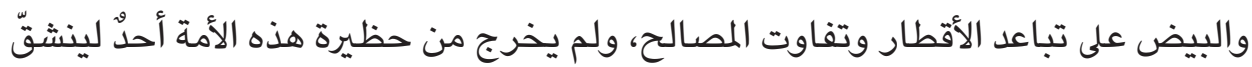

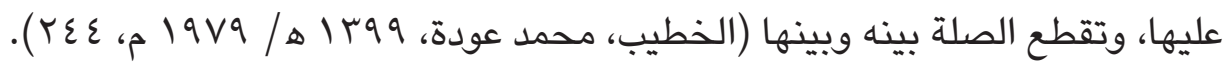

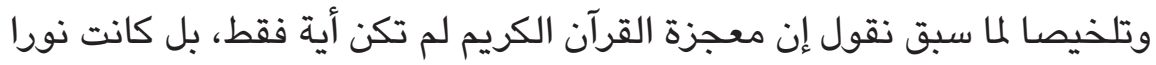

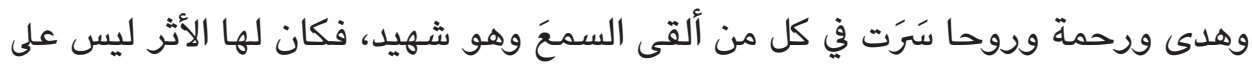

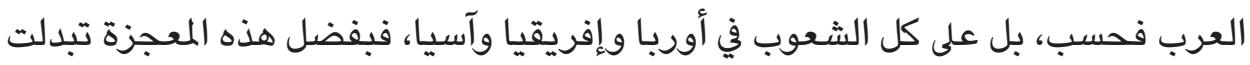

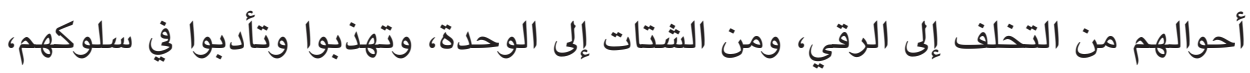

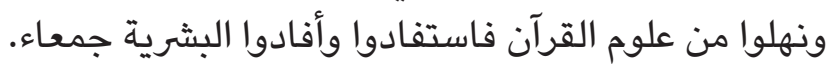

خاتمت

أحمدك ربي على جميع نعمك وآلائك وعلى توفيقك لي في إتمام هذا البحث عن (معجزة

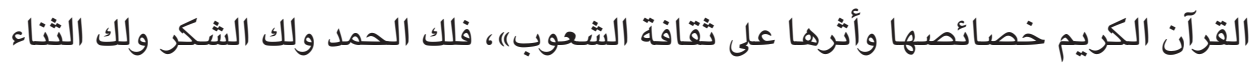

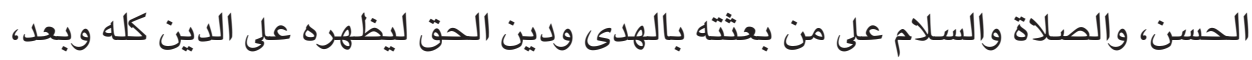

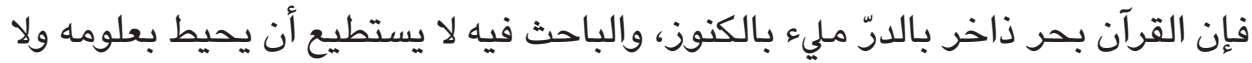

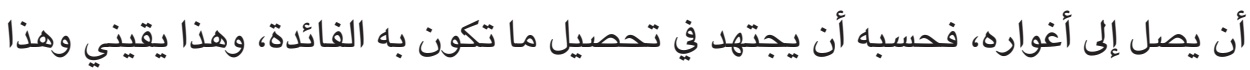
هو جهدي في هذا البحث، لا أدعي أنني قد أحطت بكل جوانبه فإن القرآن لا يحيط به به إنها علما إلا العليم الخبير جل جلاله.

وختاما لهذا البحث، هذه بعض جل النتائج التي توصلت إليها من خلاله ومنها: أن معجزة القرآن تميزت بخصائص عدة جعلتها معجزة فريدة ومتميزة فهي:

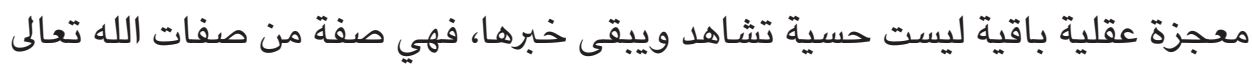
وهي كلامه فكانت باقية ببقاء من وصف بها وهاتية لوهو الله جل جلاله.

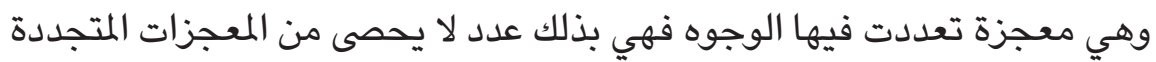
مع مر العصور وهي بذلك موافقة لطبيعة الرسالة الخاتمة. وهي ببقائها وحفظها من التحريف والتغيير قد كانت خير حافظ وخير شاهد التهالها لمعجزات الأنبياء السابقين. ومما تميزت به هذه المعجزة المباركة مجيء التحدي بهاء للثقلين الإنس والجن، فهي

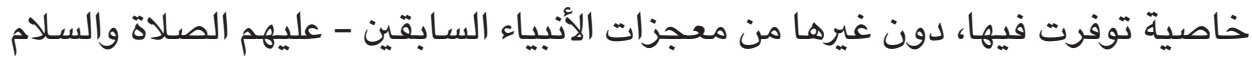
- فلم يرد عنهم أنهم قد تحدوا بمعجزاتهم غير أقوامهم ومن يدعونهم من الإنس. 
وهي مع ذلك معجزة تغلغلت في النفوس واستولت على القلوب لما فيها من الوقع العجيب والتأثير القوي كيف لا وهي كلام رب العالمين خالق القلوب والنفوس. ويهذه الخصائص مجتمعة كان لها الأثر الواضح في كل الشعوب، فقد فئ غيرت معتقداتهم، وتصوراتهم، وعدلت سلوكهم وثقافتهم إلى ما هو أقوم.

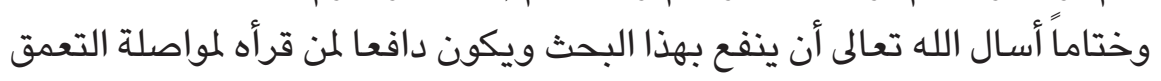
والكتابة في خصائص معجزة القرآن.

المراجع

القرآن الكريم. المدينة المنورة: طبعة مجمع الملك فهد.

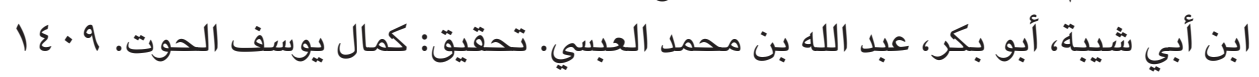

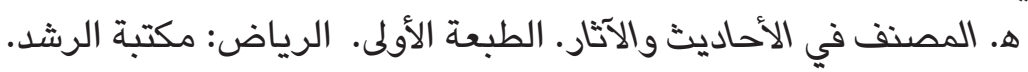

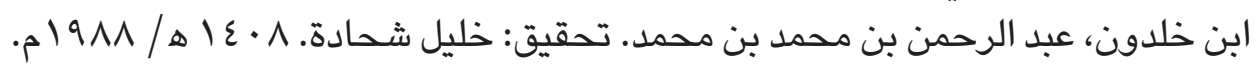

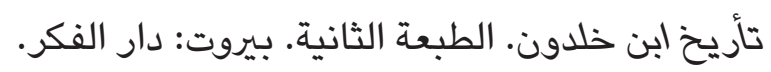

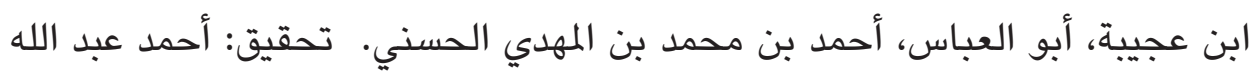
القرشي رسلان. 9 اع| هـ. البحر المديد في تفسير القرآن المجيد. الطبعة الأولى. القاهرة: الدكتور حسن عباس زكي.

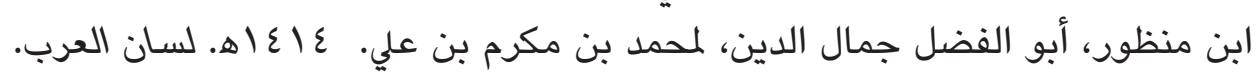
بيروت: دار صادر.

أبو حيان، محمد بن يوسف بن علي بن يوسف بن حيان. تحقيق: صدقي محمد جميل.

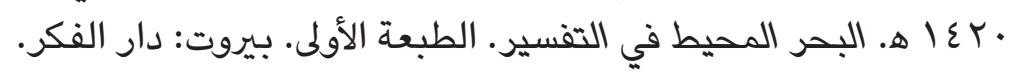

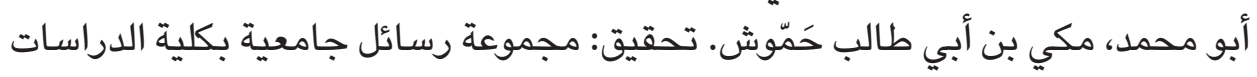

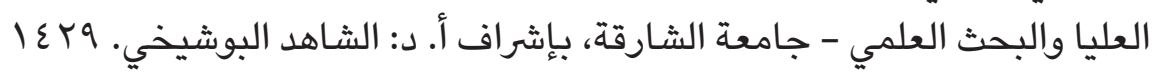
هـ ^ • • ץ م. الهداية إلى بلوغ النهاية في علم معاني القرآن وتفسيره، وأحكامه.

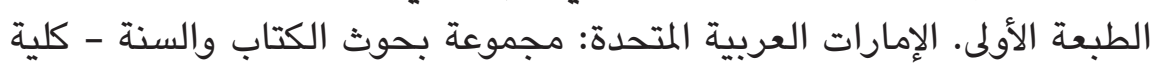
الشريعة والدراسات الإسلامية - جامعة الشارقة.

البخاري، أبو عبد الله، محمد بن إسماعيل. الجامع الصحيح. بيروت: دار طوق النجاة.

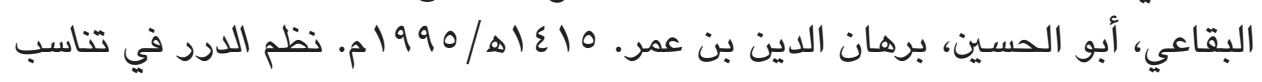
الآيات والسور. بيروت: دار الكتب العلمية. 
الترمذي، محمد بن عيسى. 19 ا 1900 م. سنن الترمذي. مصر: مكتبة ومطبعة مصطفى الحلبي.

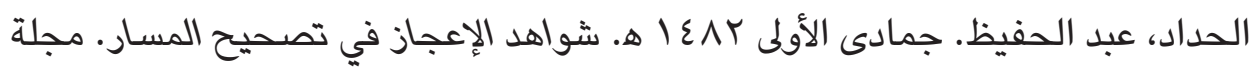

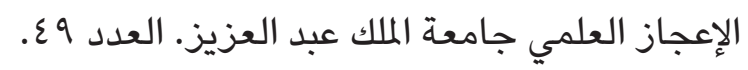

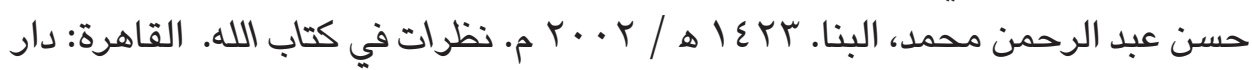

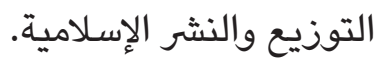

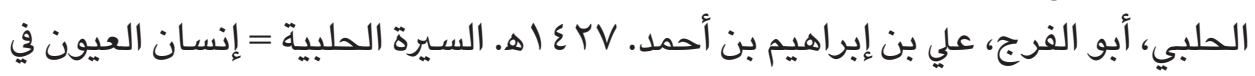

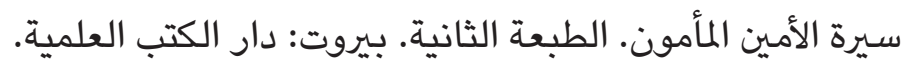

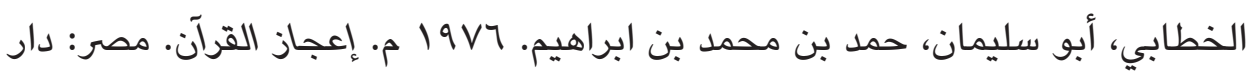

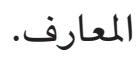

الخطيب، محمد عودة. 999 ا هـ / 9 / م. لمحات من الثقافة الإسلامية. بيروت: مؤسسة

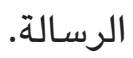

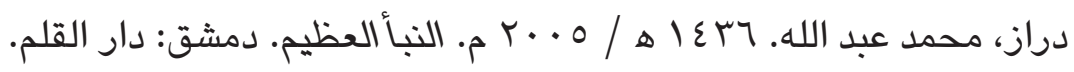

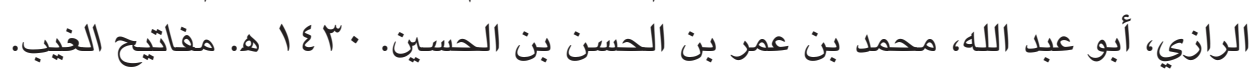

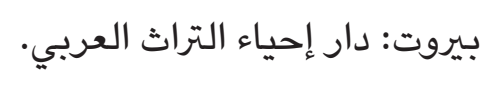

الزرقاني، محمد عبد العظيم. د.ت. مناهل العرفان في علوم القرآن. القاهرة: عيسى البابي

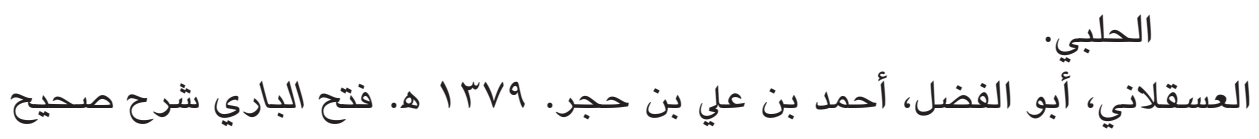

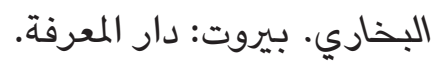

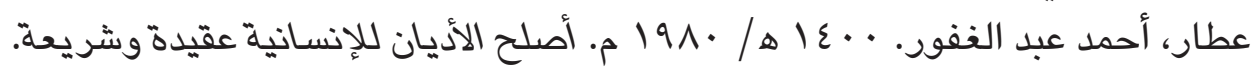

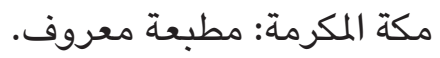

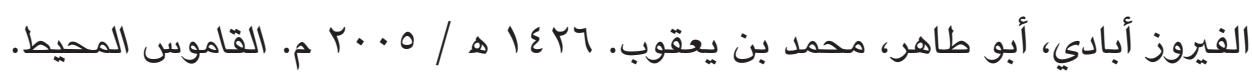

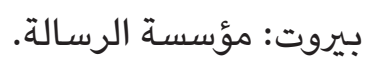

القاضي عياض، أبو الفضل. 9 • ع 1 هـ / 1911 م. الشفا بتعريف حقوق المصطفى.

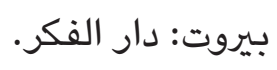

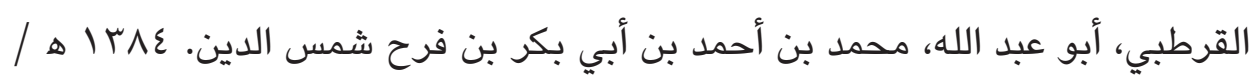

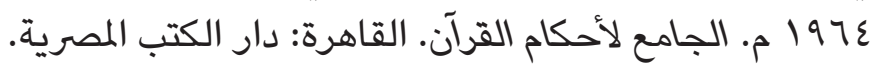


سيد قطب إبراهيم حسين الشاربي. ر | I ا هـ ـ في ظلال القرآن. الطبعة السابعة عشر.

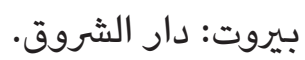

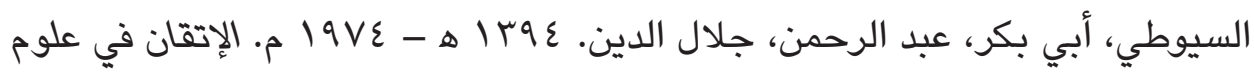

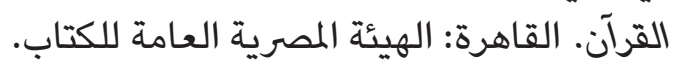

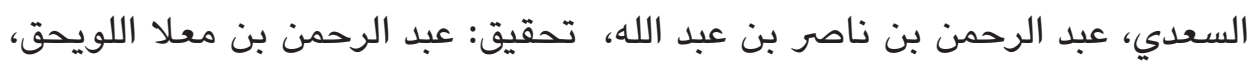

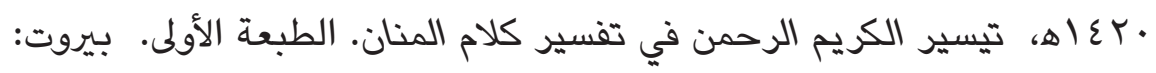

$$
\text { مؤسسة الرسالة. }
$$

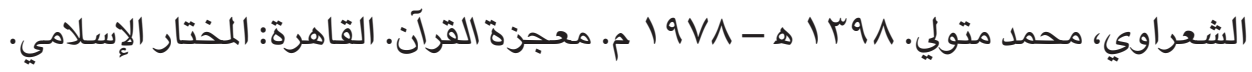

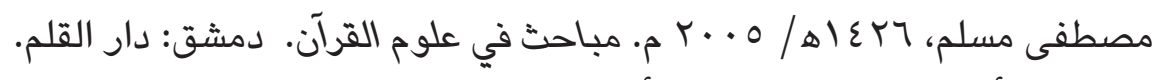

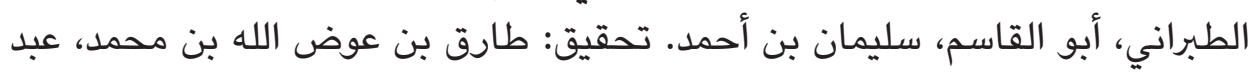

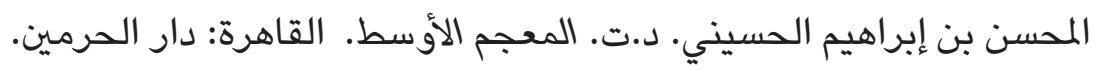

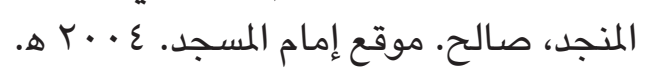
https: / / www.alimam.ws/ref/Vrr 